Article

\title{
Binuclear Copper(I) Borohydride Complex Containing Bridging Bis(diphenylphosphino) Methane Ligands: Polymorphic Structures of $\left[\left(\mu_{2}-\mathrm{dppm}\right)_{2} \mathrm{Cu}_{2}\left(\eta^{2}-\mathrm{BH}_{4}\right)_{2}\right]$ Dichloromethane Solvate
}

\author{
Natalia V. Belkova ${ }^{1}$ (D), Igor E. Golub ${ }^{1,2}$ (D), Evgenii I. Gutsul ${ }^{1}$, Konstantin A. Lyssenko ${ }^{1}$, \\ Alexander S. Peregudov ${ }^{1}$, Viktor D. Makhaev ${ }^{3}$, Oleg A. Filippov ${ }^{1}$ (D), Lina M. Epstein ${ }^{1}$, \\ Andrea Rossin 4 (D), Maurizio Peruzzini ${ }^{4}$ and Elena S. Shubina ${ }^{1, *}$ \\ 1 A. N. Nesmeyanov Institute of Organoelement Compounds, Russian Academy of Sciences (INEOS RAS), \\ 119991 Moscow, Russia; nataliabelk@ineos.ac.ru (N.V.B.); seraph347@gmail.com (I.E.G.); \\ evgenii@ineos.ac.ru (E.I.G.); kostya@xray.ineos.ac.ru (K.A.L.); asp@ineos.ac.ru (A.S.P.); \\ h-bond@ineos.ac.ru (O.A.F.); epst@ineos.ac.ru (L.M.E.) \\ 2 Inorganic Chemistry Department, Peoples' Friendship University of Russia (RUDN University), \\ 117198 Moscow, Russia \\ 3 Institute of Problems of Chemical Physics, Russian Academy of Sciences (IPCP RAS), \\ 142432 Moscow, Russia; vim@icp.ac.ru \\ 4 Istituto di Chimica dei Composti Organometallici Consiglio Nazionale delle Ricerche (ICCOM CNR), \\ 50019 Sesto Fiorentino, Italy; andrea.rossin@iccom.cnr.it (A.R.); maurizio.peruzzini@iccom.cnr.it (M.P.) \\ * Correspondence: shu@ineos.ac.ru; Tel.: +7-495-135-5085
}

Academic Editor: Sławomir J. Grabowski

Received: 18 September 2017; Accepted: 17 October 2017; Published: 20 October 2017

\begin{abstract}
Bis(diphenylphosphino)methane copper(I) tetrahydroborate was synthesized by ligands exchange in bis(triphenylphosphine) copper(I) tetrahydroborate, and characterized by XRD, FTIR, NMR spectroscopy. According to XRD the title compound has dimeric structure, $\left[\left(\mu_{2} \text {-dppm }\right)_{2} \mathrm{Cu}_{2}\left(\eta_{2}-\mathrm{BH}_{4}\right)_{2}\right]$, and crystallizes as $\mathrm{CH}_{2} \mathrm{Cl}_{2}$ solvate in two polymorphic forms (orthorhombic, 1, and monoclinic, 2) The details of molecular geometry and the crystal-packing pattern in polymorphs were studied. The rare Twisted Boat-Boat conformation of the core $\mathrm{Cu}_{2} \mathrm{P}_{4} \mathrm{C}_{2}$ cycle in $\mathbf{1}$ is found being more stable than Boat-Boat conformation in $\mathbf{2}$.
\end{abstract}

Keywords: copper(I); diphosphine; dppm ligand; tetrahydroborate; binuclear complex; crystal structure; conformations; polymorph; hydride-halogen bonding

\section{Introduction}

The concept of cooperative catalytic effects [1] in multinuclear transition metal systems led to the broad development and extensive investigation of the chemistry of transition metal complexes, bearing "short-bite" ligands that are able to lock two or more metallocenters in close proximity [2-7]. Such compounds are of great interest due to their catalytic activity including the transformation of small molecules on metal centres [8,9], they can also be used as synthetic models of enzyme action [10-12].

Phosphines are ubiquitous ligands in transition metal chemistry. Among various types of diphosphine ligands, bis-(diphenylphosphino)methane (dppm) is one of the very efficient bridging ligands [2]. As other diphosphine ligands it is able to chelate metals, but rarely acts as a bidentate ligand ( $\eta^{2}$-dppm), forming a strained four-membered cycle (Scheme 1) [13-17]. Rather, it has a tendency to act as either a monodentate $\left(\eta^{1}-\mathrm{dppm}\right)$ or bridging bidentate ligand $\left(\mu_{2}\right.$-dppm) [18]. Many examples 
of binuclear complexes containing the eight-membered ring $\mathrm{M}\left(\mu_{2} \text {-dppm }\right)_{2} \mathrm{M}^{\prime}$ are known with a variety of metals and stereochemistries [18].<smiles>[M][PH]1(c2ccccc2)CP(c2ccccc2)(c2ccccc2)(c2ccccc2)C1</smiles>

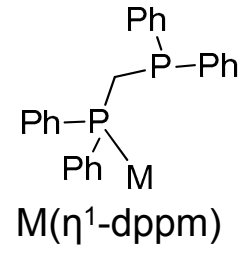<smiles>[M]OP(CP(c1ccccc1)c1ccccc1)P(c1ccccc1)c1ccccc1</smiles>

Scheme 1. Possible coordination modes of dppm ligand in transition metal complexes.

The $\mathrm{Cu}(\mathrm{I})$-dppm complexes are emerging class of polynuclear complexes, that are drawing considerable attention because of their photophysical properties [19-22] and prospective use as a catalyst [23-25] and a sensor for various organic bases [26] and anions [27]. Binuclear $\mathrm{Cu}(\mathrm{I})$ species possess an enhanced reactivity toward organic azides in copper-catalysed azide-alkyne cycloaddition compared to monomeric copper complexes [28-35]. Copper(I) tetrahydroborates with phosphine ligands featuring relative stability to air oxygen and moisture are used as selective reducing agents [36-40], catalysts of photosensitized isomerization of dienes [41-43] and hydrolytic dehydrogenation of ammonia borane [44]. Since metal tetrahydroborates have great potential in hydrogen storage technology [45-50], as catalysts [51-55] and selective reducing agents [56-61] their structural and dynamic properties have been actively investigated [52,62-64]. These studies revealed different modes of $\mathrm{BH}_{4}{ }^{-}$coordination to the metal atom, which can behave as mono-, bi-, or tridentate ligand [64].

Our studies of intermolecular interactions of $\mathrm{BH}_{4}^{-}[65,66]$ and several metal tetrahydroborates [67-70] with proton donors have shown the versatility of dihydrogen bonded (DHB) complexes formed and their crucial role in the reactivity of these compounds. In particular, we have shown that the formation of bifurcate DHB complexes involving both bridging and terminal hydride hydrogens of $\left(\mathrm{Ph}_{3} \mathrm{P}\right)_{2} \mathrm{Cu}\left(\eta^{2}-\mathrm{BH}_{4}\right)$ (Scheme 2) is prerequisite for the subsequent proton transfer and dimerization to occur [67]. Continuing these studies, we attempted the synthesis of $\left(\eta^{2}-\mathrm{dppm}\right) \mathrm{Cu}\left(\eta^{2}-\mathrm{BH}_{4}\right)$ following the published recipe [71]. However, in our hands, it gave, instead, a binuclear dimer bearing two bridging $\mu_{2}$-dppm ligands between the two $\left\{\mathrm{Cu}\left(\eta^{2}-\mathrm{BH}_{4}\right)\right\}$ moieties. Herein we describe its spectroscopic characterization and analysis of polymorphic structures of its dichloromethane solvate.

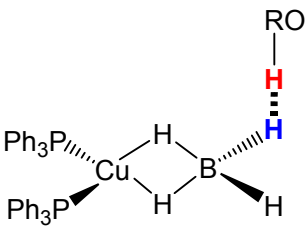

Ia

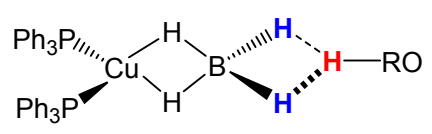

IIa

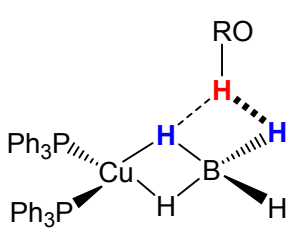

IIab

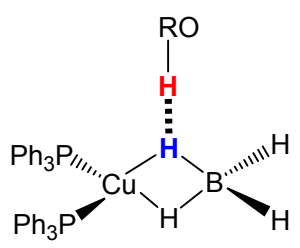

Ib

Scheme 2. Possible structures of DHB complexes. Adapted with permission from ref [67]. Copyright 2012 American Chemical Society.

\section{Experimental Section}

All manipulations were performed under a dry argon atmosphere using the standard Schlenk technique. Commercially-available argon (99.9\%) was additionally purified from traces of oxygen and moisture by sequential passage through $\mathrm{Ni} / \mathrm{Cr}$ catalyst column and $4 \AA$ molecular sieves.

The HPLC grade solvents (Acros Organics, Morris Plains, NJ, United States) were used for sample preparation after additional purification by standard procedures. Dichloromethane (DCM) and 
toluene were dehydrated over $\mathrm{CaH}_{2}$ and Na/benzophenone, respectively. All solvents were freshly distilled under argon prior to use. Deuterated solvent $\left(\mathrm{CD}_{2} \mathrm{Cl}_{2}\right)$ was dehydrated over $\mathrm{CaH}_{2}$ and was distilled and degassed by three freeze-pump-thaw cycles prior to use. Bis(diphenylphosphino)methane (dppm) from Sigma Aldrich (St. Louis, MO, USA) was used without additional purification. Bis(triphenylphosphine) copper(I) tetrahydroborate was prepared following the previously-described procedure [67].

IR spectra were recorded on Shimadzu IR Prestige21 (Shimadzu Corporation, Kyoto, Japan) and Nicolet 6700 FTIR (Thermo Fisher Scientific, Waltham, MA, USA) spectrometers in KBr pellets and Nujol mull in thin polyethylene film. NMR spectra were recorded on a Bruker Avance II 500 and $600 \mathrm{MHz}$ spectrometers (Bruker Corporation, Billerica, MA, USA). ${ }^{1} \mathrm{H}$ and ${ }^{13} \mathrm{C}\left\{{ }^{1} \mathrm{H}\right\}$ chemical shifts are reported in parts per million (ppm) downfield to tetramethylsilane (TMS) and were calibrated against the residual solvent resonance, while ${ }^{31} \mathrm{P}\left\{{ }^{1} \mathrm{H}\right\}$ spectra were referenced to $85 \% \mathrm{H}_{3} \mathrm{PO}_{4}$ with a downfield shift taken as positive; ${ }^{11} \mathrm{~B}$ spectra were referenced to $\mathrm{BF}_{3} \cdot \mathrm{Et}_{2} \mathrm{O}$. The ${ }^{13} \mathrm{C}\left\{{ }^{1} \mathrm{H}\right\} \mathrm{NMR}$ spectra were registered using the JMODECHO mode; the signals for the $\mathrm{C}$ atoms bearing odd and even numbers of protons have opposite polarities.

\subsection{Preparation of $\mu_{2}$-Bis(Diphenylphosphino)Methane Copper(I) Tetrahydroborate $\left[\left(\mu_{2}-d p p m\right)_{2} C u_{2}\right]\left[\eta^{2}-B H_{4}\right]_{2}$}

The complex was synthesized through a slight modification of a previously described procedure [71]. Bis(diphenylphosphino)methane (dppm) $(0.5 \mathrm{~g}, 1.32 \mathrm{mmol})$ were added to a solution of bis(triphenylphosphine) copper(I) tetrahydroborate $(0.8 \mathrm{~g}, 1.32 \mathrm{mmol})$ in $50 \mathrm{ml}$ toluene. The reaction mixture was stirred for $3 \mathrm{~h}$ at $60^{\circ} \mathrm{C}$, then cooled to room temperatures and refrigerated $\left(-15{ }^{\circ} \mathrm{C}\right)$ to afford the white powder precipitate $(0.3 \mathrm{~g})$ of pure $\mu_{2}$-bis(diphenylphosphino)methane copper(I) tetrahydroborate (yield: $48 \%$ ). The monocrystals suitable for XRD analysis were obtained by slow solvent evaporation from $\mathrm{CH}_{2} \mathrm{Cl}_{2}(\mathrm{DCM})$ solution under an argon stream.

${ }^{1} \mathrm{H}$ NMR (500 MHz, $\left.\mathrm{CD}_{2} \mathrm{Cl}_{2}, 298 \mathrm{~K}, \mathrm{ppm}\right): 1.26$ (br d, $\mathrm{BH}_{4}{ }^{-}$), 2.88 (br q, $\left.\mathrm{CH}_{2}\right), 7.11$ (t, meta $\mathrm{Ph}), 7.26$ (t, para Ph), 7.33 (multiplet, ortho $\mathrm{Ph}) .{ }^{31} \mathrm{P}\left\{{ }^{1} \mathrm{H}\right\} \mathrm{NMR}\left(202 \mathrm{MHz}, \mathrm{CD}_{2} \mathrm{Cl}_{2}, 298 \mathrm{~K}, \mathrm{ppm}\right)$ : $-14.6 \div-16.5$ (s) depending on conc. ${ }^{11} \mathrm{~B}$ NMR $\left(160 \mathrm{MHz}, \mathrm{CD}_{2} \mathrm{Cl}_{2}, 298 \mathrm{~K}, \mathrm{ppm}\right):-29.81$ (broad multiplet). ${ }^{13} \mathrm{C}$ NMR (126 MHz, $\mathrm{CD}_{2} \mathrm{Cl}_{2}, 298 \mathrm{~K}$, ppm) 25.74 (multiplet $\mathrm{CH}_{2}$ ), 129.93 (s) para $\mathrm{Ph}$, 128.52 (s) meta $\mathrm{Ph}, 132.58$ multiplet orto $\mathrm{Ph}, 132.99$ multiplet ipso $\mathrm{C} \mathrm{Ph}$.

FTIR: 3075, 3049, 2382, 2360, 2294, 2249, 2019, 1967, 1934, 1484, 1433, 1384, 1368, 1331, 1312, 1278 , $1187,1158,1133,1095,1025,999,918,848,777,766,741,734,719,693,516,507,477 \mathrm{~cm}^{-1}$ (KBr pellet); $521,516,507,477,430,420,412,358 \mathrm{~cm}^{-1}$ (Nujol mull/polyethylene film).

Several attempts to obtain the pure complex by recrystallization from toluene gave samples containing the traces of this solvent. The satisfactory elemental analysis was obtained for the sample which contains according to ${ }^{1} \mathrm{H}$ NMR approximately 0.7 molecules of toluene per one molecule of the copper dimer. Anal. calcd. for $\mathrm{C}_{50} \mathrm{H}_{52} \mathrm{~B}_{2} \mathrm{Cu}_{2} \mathrm{P}_{4}$ : C, 64.88; H, 5.66; B, 2.34; $\mathrm{Cu}, 13.73 ; \mathrm{P}, 13.39$. Found: $\mathrm{C}$, 66.55; H, 5.83; B, 2.29; P, 12.71.

\subsection{Computational Details}

Full geometry optimization of $\mathbf{1}$ and $\mathbf{2}$ (with removed solvent molecules) was performed with the Gaussian09 (Revision D.01, Gaussian, Wallingford, CT, USA) [72] software package. The model was described by M06 [73], B3LYP [74-76], BP86 [77], and PBE0 [78] methods with spin-state-corrected s6-31G(d) [79] basis set for $\mathrm{Cu}$ atom and 6-311++G(d,p) for atoms of the $\mathrm{BH}_{4}^{-}$and alcohol OH-groups [80,81]; 6-31G(d) for the phosphorus atoms [82]; and 6-31G for the carbon and hydrogen atoms of dppm ligand $[80,83,84]$. For B3LYP, BP86 and PBE0 functionals empirical dispersion correction suggested by Grimme (GD2 [85] and GD3BJ [86,87]) was applied. Frequency calculations were performed for all optimized complexes in the gas phase and are reported without the use of scaling factors. The nature of all the stationary points on the potential energy surfaces was confirmed by an absence of any imaginary frequencies in the vibrational analysis [88]. 
The inclusion of nonspecific solvent effects in the calculations was performed by using the SMD method [89]. The solute cavity was redefined with radii $=\mathrm{UAHF}$, because this atomic cavity was found to be more suitable than the default atom cavity (radii = SMD-Coulomb) defined in the SMD model $[70,90]$. The interaction energies were calculated in $\mathrm{CH}_{2} \mathrm{Cl}_{2}(\varepsilon=8.9)$ for the gas phase optimized geometries. Changes in Gibbs energies and enthalpies in the solvent were determined using corresponding corrections obtained for the gas phase [91]:

$$
\begin{aligned}
& \Delta \mathrm{H}_{\text {Solv. }}=\Delta \mathrm{E}_{\text {Solv. }}+\Delta \mathrm{H}_{\text {gas }}^{\text {corr }} \\
& \Delta \mathrm{G}_{\text {Solv. }}=\Delta \mathrm{E}_{\text {Solv. }}+\Delta \mathrm{G}_{\text {gas }}^{\text {corr }}
\end{aligned}
$$

\subsection{X-ray Crystallography}

X-ray diffraction data were collected on an Bruker APEX II CCD diffractometer (Bruker Corporation, Billerica, MA, United States) using molybdenum radiation $[\lambda(\mathrm{MoK} \alpha)=0.71072 \AA$, $\omega$-scans] for $\mathbf{1}$ and $\mathbf{2}$. The substantial redundancy in data allowed an empirical absorption correction to be applied with SADABS by multiple measurements of equivalent reflections. The structures were solved by direct methods and refined by the full-matrix least-squares technique against $F^{2}$ in the anisotropic-isotropic approximation.

The positional and anisotropic displacement parameters of the disordered $\mathrm{CH}_{2} \mathrm{Cl}_{2}$ in $\mathbf{1}$ and $\mathbf{2}$ were refined with the constraints on the $\mathrm{C}-\mathrm{Cl}$ bond length (DFIX) and anisotropic displacement parameters (EADP). $\mathrm{C}-\mathrm{H}$ hydrogen atoms in all structures were placed in calculated positions and refined within the riding model. Hydrogen atoms of $\mathrm{BH}_{4}{ }^{-}$group in both structures were located from the Fourier density synthesis and refined in the riding model. All calculations were performed with the SHELXTL software package [92]. Crystal data and structure refinement parameters are listed in Table 1. Crystallographic data for the structures reported in this paper have been deposited to the Cambridge Crystallographic Data Centre as supplementary no.: CCDC-1572389 (for 1) and CCDC-1572388 (for 2). These data can be obtained free of charge from Cambridge Crystallographic Data via www.ccdc.cam.ac.uk/data_request/cif.

Table 1. Crystal data and structure refinement parameters for $\mathbf{1}$ and 2.

\begin{tabular}{ccc}
\hline & $\mathbf{1}$ & $\mathbf{2}$ \\
\hline Brutto formula & $\mathrm{C}_{50} \mathrm{H}_{52} \mathrm{~B}_{2} \mathrm{Cu}_{2} \mathrm{P}_{4}, \mathrm{CH}_{2} \mathrm{Cl}_{2}$ & $\mathrm{C}_{50} \mathrm{H}_{52} \mathrm{~B}_{2} \mathrm{Cu}_{2} \mathrm{P}_{4}, 0.5 \mathrm{CH}_{2} \mathrm{Cl}_{2}$ \\
Formula weight & 1010.42 & 967.96 \\
$\mathrm{~T}, \mathrm{~K}$ & 120 & 120 \\
Space group & $\mathrm{P}{ }_{1} 2_{1} 2_{1}$ & $\mathrm{P}{ }_{1} / \mathrm{c}$ \\
$\mathrm{Z}\left(\mathrm{Z}^{\prime}\right)$ & $4(1)$ & $4(1)$ \\
$\mathrm{a} / \AA$ & $14.218(2)$ & $23.0884(18)$ \\
$\mathrm{b} / \AA$ & $17.875(3)$ & $13.0448(10)$ \\
$\mathrm{c} / \AA$ & $19.523(3)$ & $16.0830(13)$ \\
$\beta /{ }^{\circ}$ & 90.00 & $92.055(2)$ \\
Volume $^{\circ} \AA^{3}$ & $4961.7(13)$ & $4840.8(7)$ \\
$\rho_{\text {calc }}, \mathrm{g} / \mathrm{cm}^{3}$ & 1.353 & 1.328 \\
$\mu / \mathrm{cm}^{-1}$ & 11.28 & 10.99 \\
$\mathrm{~F}(000)$ & 2088 & 2004 \\
$2 \theta_{\text {max }}{ }^{\circ}$ & 58 & 58 \\
Reflections collected $\left(\mathrm{R}_{\text {int }}\right)$ & $50,044(0.0480)$ & 12851 \\
Independent reflections & 13140 & 9781 \\
Reflections with $\mathrm{I}>2 \sigma(\mathrm{I})$ & 11874 & 576 \\
Parameters & 547 & 0.0368 \\
$\mathrm{R}_{1}[\mathrm{I}>2 \sigma(\mathrm{I})]$ & 0.0604 & 0.0974 \\
w $\mathrm{R}_{2}$ & 0.1569 & 1.018 \\
$\mathrm{GOF}$ & 1.094 & $-0.730 / 0.840$ \\
\hline
\end{tabular}




\section{Results and Discussion}

\subsection{Experimental Characterization}

The title copper(I) tetrahydroborate was synthesized by the ligand exchange in a manner similar to that given in [71], where of the reaction product was described as $\left(\eta^{2}-\mathrm{dppm}\right) \mathrm{Cu}\left(\eta^{2}-\mathrm{BH}_{4}\right)$. In our hands the procedure described in the Experimental Section yielded, upon recrystallization from $\mathrm{CH}_{2} \mathrm{Cl}_{2}$, a bimetallic complex with two bridging dppm ligands $\left[\left(\mu_{2}-\mathrm{dppm}\right)_{2} \mathrm{Cu}_{2}\right]\left[\eta^{2}-\mathrm{BH}_{4}\right]_{2}$, the possible formation of such compound was suggested earlier in [93].

The ${ }^{1} \mathrm{H}$ NMR spectrum (Figure S1) of the complex obtained exhibits the signals of phenyl protons around $\delta_{\mathrm{Ph}}=7.26 \mathrm{ppm}$, methylene protons $\delta_{\mathrm{CH} 2}=2.88 \mathrm{ppm}$, and broad multiplet at $\delta_{\mathrm{BH} 4}=1.26 \mathrm{ppm}$ belonging to borohydride protons. The ${ }^{11} \mathrm{~B}$ NMR spectrum (Figure S2) consists of a broad multiplet at $-29.81 \mathrm{ppm}$, which is similar to the resonance of the monometallic $\left(\mathrm{Ph}_{3} \mathrm{P}\right)_{2} \mathrm{Cu}\left(\eta^{2}-\mathrm{BH}_{4}\right)$ $\left(\delta_{\mathrm{B}}=-29.79 \mathrm{ppm}\right)$ [67]. The ${ }^{31} \mathrm{P}\left\{{ }^{1} \mathrm{H}\right\}$ spectrum (Figure S3) shows only one singlet at $-14.6 \div-16.5$ (s) ppm (depending on concentration), which means the phosphorus atoms are magnetically equivalent. The signal is deshielded compared to the free dppm ligand $\left(\delta_{P}=-21.7\right)$; at the same time its position is significantly different from that reported for monometallic dppm compound [71] (-148 ppm relative to $(\mathrm{MeO})_{3} \mathrm{P}$ as a reference which is $140 \mathrm{ppm}$ relative to $85 \% \mathrm{H}_{3} \mathrm{PO}_{4}$ used in this work). In the ${ }^{13} \mathrm{C}\left\{{ }^{1} \mathrm{H}\right\}$ NMR (see Figures S4-S7) hydrogen and carbon atoms of methylene bridge ( -25.9 ppm) and carbon atoms in phenyl rings (ortho and ipso ones) give centrosymmetric multiplets (see Figures S5 and S6). For the sake of comparison the ${ }^{31} \mathrm{P}\left\{{ }^{1} \mathrm{H}\right\}$ and ${ }^{1} \mathrm{H}$ NMR spectra of $\left[\left(\mu_{2}-\mathrm{dppm}\right)_{2} \mathrm{Cu}_{2}\right]\left[\eta^{2}-\mathrm{BH}_{4}\right]_{2}$ were also measured in $\mathrm{CDCl}_{3}$ (Figure S10).

FTIR spectra in the KBr pellets of 1 and 2 (Figures S8 and S9) show two $\mathrm{BH}_{\text {term }}$ at 2382 and $2360 \mathrm{~cm}^{-1}$ and two $\mathrm{BH}_{\mathrm{br}}$ stretching vibrations at 2019 and $1967 \mathrm{~cm}^{-1}, \mathrm{BH}_{2}$ deformation at $1133 \mathrm{~cm}^{-1}$ (Table 2) and a band at $358 \mathrm{~cm}^{-1}$, which can be attributed to the vibrations of the four-membered $\mathrm{CuHBH}$ cycle $\left(v_{\mathrm{CuB}}\right)[67,94]$. The positions of these bands are within the range reported for bis-phosphine $\left\{\mathrm{Cu}\left(\eta^{2}-\mathrm{BH}_{4}\right)\right\}$ complexes (Table 2). Moreover, they coincide with those reported previously for the analogue dppm compound formulated as $(\mathrm{dppm}) \mathrm{Cu}\left(\eta^{2}-\mathrm{BH}_{4}\right)$ [94].

Table 2. Characteristic vibrations observed in IR spectra and ${ }^{11} \mathrm{~B}$ NMR chemical shifts of the $\mathrm{BH}_{4}{ }^{-}$ group reported for copper(I) tetrahydroborate complexes.

\begin{tabular}{|c|c|c|c|c|c|c|}
\hline Compound & $v_{\text {BHterm }}$ & $v_{\mathrm{BHbr}}$ & $\delta_{\mathrm{BH} 2}$ & $v_{\mathrm{CuB}}$ & $\delta_{\mathrm{BH} 4}$ & Ref. \\
\hline$\left[(\mathrm{EtO})_{3} \mathrm{P}\right]_{2} \mathrm{Cu}\left(\eta^{2}-\mathrm{BH}_{4}\right)$ & 2380,2350 & 1990,1930 & 1135 & - & $-29.1^{c}$ & [95] \\
\hline$\left[\left(\mu_{2}-\mathrm{dppm}\right)_{2} \mathrm{Cu}_{2}\right]\left[\eta^{2}-\mathrm{BH}_{4}\right]_{2}$ & 2382,2360 & 2019,1967 & 1133 & 358 & $-29.5^{b}$ & This work \\
\hline$\left(\mathrm{PPh}_{3}\right)_{2} \mathrm{Cu}\left(\eta^{2}-\mathrm{BH}_{4}\right)$ & 2403,2394 & 1994,1937 & 1142 & 374 & $-29.7^{b}$ & {$[67,96]$} \\
\hline$\left[\left\{\mathrm{Ph}_{2} \mathrm{P}\left(\mathrm{CH}_{2}\right)_{2}\right\}_{2} \mathrm{NCH}_{2}\right]_{2} \mathrm{Cu}\left(\eta^{2}-\mathrm{BH}_{4}\right)$ & 2365 & 2010 & 1120 & - & $-30.2^{c}$ & [97] \\
\hline$\left[(\mathrm{MeO})_{3} \mathrm{P}\right]_{2} \mathrm{Cu}\left(\eta^{2}-\mathrm{BH}_{4}\right)$ & 2380,2345 & 1990, 1935 & 1135 & - & $-30.4^{c}$ & [95] \\
\hline$(\mathrm{dppm}) \mathrm{Cu}\left(\mathrm{\eta}^{2}-\mathrm{BH}_{4}\right)$ & 2382,2360 & 2018,1965 & 1130 & 358 & - & [94] \\
\hline$"\left[\left(\mu_{2}-\mathrm{dppm}\right)_{2} \mathrm{Cu}_{2}\right]\left[\eta^{2}-\mathrm{BH}_{4}\right]_{2} "$ & 2391,2345 & 1987,1924 & 1144 & - & - & [93] \\
\hline$"\left(\eta^{2}-\mathrm{dppm}\right) \mathrm{Cu}\left(\eta^{2}-\mathrm{BH}_{4}\right)^{\prime \prime}$ & 2370,2229 & 1984,1949 & 1185 & $378^{\text {a }}$ & - & [71] \\
\hline (dppe) $\mathrm{Cu}\left(\eta^{2}-\mathrm{BH}_{4}\right)$ & 2384,2341 & 1990,1928 & 1141 & - & - & [93] \\
\hline (dppe) $\mathrm{Cu}\left(\eta^{2}-\mathrm{BH}_{4}\right)$ & 2380,2360 & 2010,1950 & 1140 & 355 & - & [94] \\
\hline$(\mathrm{dppb}) \mathrm{Cu}\left(\eta^{2}-\mathrm{BH}_{4}\right)$ & 2385,2360 & 1985,1950 & 1140 & - & - & [94] \\
\hline$(\mathrm{dpph}) \mathrm{Cu}\left(\eta^{2}-\mathrm{BH}_{4}\right)$ & 2388,2360 & 1982,1940 & 1140 & 356 & - & [94] \\
\hline$\left(\mathrm{F}_{\mathrm{CPPh}}\right)_{2} \mathrm{Cu}\left(\mathrm{\eta}^{2}-\mathrm{BH}_{4}\right)$ & 2398,2360 & 2005,1960 & 1140 & - & - & {$[94,98]$} \\
\hline$\left(\mathrm{Fc}_{2} \mathrm{PPh}\right)_{2}\left(\mathrm{\eta}^{2}-\mathrm{BH}_{4}\right)$ & 2398,2360 & 2005,1950 & 1140 & 368 & - & [94] \\
\hline$(\mathrm{dppf}) \mathrm{Cu}\left(\mathrm{n}^{2}-\mathrm{BH}_{4}\right)$ & 2397,2354 & 2013,1970 & 1130 & 376 & - & [94] \\
\hline$\left({ }^{n} \mathrm{BuPPh}_{2}\right)_{2} \mathrm{Cu}\left(\mathrm{n}^{2}-\mathrm{BH}_{4}\right)$ & 2404,2394 & 1995,1937 & 1139 & 363 & - & {$[96,99]$} \\
\hline$\left[(\mathrm{EtO})_{3} \mathrm{P}\right]_{2} \mathrm{Cu}\left(\mathrm{\eta}^{2}-\mathrm{BH}_{4}\right)$ & 2397,2360 & 1994,1933 & 1137 & 386 & - & {$[96]$} \\
\hline$\left.\left[{ }^{i} \mathrm{PrO}\right)_{3} \mathrm{P}\right]_{2} \mathrm{Cu}\left(\eta^{2}-\mathrm{BH}_{4}\right)$ & 2399,2394 & 1999,1932 & 1137 & 384 & - & [96] \\
\hline$\left[\left(\mathrm{Me}_{2} \mathrm{~N}\right)_{3} \mathrm{P}\right]_{2} \mathrm{Cu}\left(\eta^{2}-\mathrm{BH}_{4}\right)$ & 2392,2366 & 2023,1946 & 1137 & 356 & - & [96] \\
\hline$\left[\left(p-\mathrm{MeOC}_{6} \mathrm{H}_{4} \mathrm{O}\right)_{3} \mathrm{P}\right]_{2} \mathrm{Cu}\left(\eta^{2}-\mathrm{BH}_{4}\right)$ & 2385,2350 & 2005,1961 & - & - & - & [100] \\
\hline$\left[\left(p-\mathrm{MeC}_{6} \mathrm{H}_{4} \mathrm{O}\right)_{3} \mathrm{P}\right]_{2} \mathrm{Cu}\left(\eta^{2}-\mathrm{BH}_{4}\right)$ & 2382,2343 & 1990, 1930 & - & - & - & [100] \\
\hline$\left[\left(m-\mathrm{MeC}_{6} \mathrm{H}_{4} \mathrm{O}\right)_{3} \mathrm{P}\right]_{2} \mathrm{Cu}\left(\eta^{2}-\mathrm{BH}_{4}\right)$ & 2380,2343 & 2018,1944 & - & - & - & [100] \\
\hline$\left[(\mathrm{EtO})_{3} \mathrm{P}\right](\mathrm{phen}) \mathrm{Cu}\left(\mathrm{\eta}^{2}-\mathrm{BH}_{4}\right)$ & 2360,2330 & 2080 & - & - & - & [101] \\
\hline$\left(\mathrm{PPh}_{3}\right)(\mathrm{phen}) \mathrm{Cu}\left(\mathrm{\eta}^{2}-\mathrm{BH}_{4}\right)$ & 2360,2330 & 2070,1910 & 1120 & - & - & [102] \\
\hline$(\mathrm{dmdp}) \mathrm{Cu}\left(\mathrm{\eta}^{2}-\mathrm{BH}_{4}\right)$ & 2385,2350 & 1982 & 1128 & 398 & - & [102] \\
\hline (triphos) $\mathrm{Cu}\left(\eta^{1}-\mathrm{BH}_{4}\right)$ & 2354,2321 & 1988 & - & - & $-32.8^{\mathrm{b}}$ & [69] \\
\hline$\left(\mathrm{MePPh}_{2}\right)_{3} \mathrm{Cu}\left(\eta^{2}-\mathrm{BH}_{4}\right)$ & 2335,2315 & 2050 & 1075,1060 & - & $-39.0^{\mathrm{c}}$ & {$[95,103]$} \\
\hline$\left[(\mathrm{MeO})_{3} \mathrm{P}\right]_{3} \mathrm{Cu}\left(\eta^{1}-\mathrm{BH}_{4}\right)$ & 2340 & 2055 & - & - & $-39.0^{c}$ & [95] \\
\hline$\left[(\mathrm{EtO})_{3} \mathrm{P}\right]_{3} \mathrm{Cu}\left(\eta^{1}-\mathrm{BH}_{4}\right)$ & 2335 & 2055 & - & - & $-40.0^{\mathrm{c}}$ & [95] \\
\hline (triphos) $\mathrm{Cu}\left(\eta^{1}-\mathrm{BH}_{4}\right)$ & 2360,2300 & 1980 & - & - & - & [104] \\
\hline$\left(\mathrm{NP}_{3}\right) \mathrm{Cu}\left(\eta^{1}-\mathrm{BH}_{4}\right)$ & 2310 & 2060 & 1130,1060 & - & - & [104] \\
\hline$\left(\mathrm{EtP}_{3}\right) \mathrm{Cu}\left(\eta^{1}-\mathrm{BH}_{4}\right)$ & 2375 & 2000 & 1130 & - & - & [104] \\
\hline
\end{tabular}

For the ligands abbreviations see Supporting Information. ${ }^{a}$ This stretching vibration was previously described as $v_{\mathrm{CuP}}[71] ;{ }^{\mathrm{b}} \mathrm{CD}_{2} \mathrm{Cl}_{2} ;{ }^{\mathrm{c}} \mathrm{CDCl}_{3}$. 
The spectral criteria allow determining the coordination mode: the hapticity of the $\mathrm{BH}_{4}{ }^{-}$ligand. IR spectra of $\left\{\mathrm{M}\left(\eta^{1}-\mathrm{BH}_{4}\right)\right\}$ complexes show only one $\mathrm{BH}_{\mathrm{br}}$ stretching vibration instead of two $\mathrm{BH}_{\mathrm{br}}$ stretching vibrations observed for $\left\{\mathrm{M}\left(\eta^{2}-\mathrm{BH}_{4}\right)\right\}$ complexes. The latter also exhibits two resolved or one broad $\mathrm{BH}_{\text {term }}$ stretching vibrations at a higher frequency than $\left\{\mathrm{M}\left(\eta^{1}-\mathrm{BH}_{4}\right)\right\}$ (Table 2). Additionally, stretching vibration of $\mathrm{CuHBH}$ cycle is a unique feature of $\left\{\mathrm{M}\left(\eta^{2}-\mathrm{BH}_{4}\right)\right\}$ complexes [52,63]. Analysis of the data for copper(I) tetrahydroborate complexes shows that the ${ }^{11} \mathrm{~B} N M R$ chemical shift of the $\mathrm{BH}_{4}{ }^{-}$ group is slightly different for different coordination types $\left(-29.1 \div-30.2 \mathrm{ppm}\right.$ for $\left\{\mathrm{Cu}\left(\eta^{2}-\mathrm{BH}_{4}\right)\right\}$ and $-30.2 \div-40.0 \mathrm{ppm}$ for $\left.\left\{\mathrm{Cu}\left(\eta^{1}-\mathrm{BH}_{4}\right)\right\}\right)$. Thus, the spectral analysis can serve as a base for the initial assignment of the $\mathrm{BH}_{4}$ coordination mode. The $\mathrm{X}$-ray data on the $\mathrm{Cu} \cdots \mathrm{B}$ distance (vide infra) should allow to unambiguously distinguish the type of $\mathrm{BH}_{4}{ }^{-}$coordination even if the position of hydrogens could not be accurately determined [63].

The XRD analysis of monocrystals obtained for this copper(I) tetrahydroborate compound revealed it is a binuclear complex bearing two dppm ligands bridging two $\left\{\mathrm{Cu}\left(\eta^{2}-\mathrm{BH}_{4}\right)\right\}$ fragments. Previously it was found that the addition of an excess anion able to act as a capping ligand (e.g., halogen anions) can yield not only binuclear, but tri-, or even tetranuclear $\mathrm{Cu}(\mathrm{I})$-dppm complexes. However in our case, $\mathrm{BH}_{4}{ }^{-}$does not act as a capping ligand, and the trinuclear structure was found previously only once for $\left(\mu_{2}-\mathrm{PPh}_{2} \mathrm{NHPPh}_{2}\right)_{3} \mathrm{Cu}_{3}\left(\mu_{3}-\mathrm{H}\right)-\left(\mu_{3}-\mathrm{BH}_{4}\right)[105]$.

Two solvatomorphic structures were identified (Table 1, Figures 1 and 2): one of orthorhombic space group $\mathrm{P} 2{ }_{1} 2_{1} 2_{1}$ with one DCM molecule (1), and the second one of monoclinic space group P2 $2_{1} / \mathrm{c}$ with $\frac{1}{2}$ molecule of DCM per molecule of the copper complex (2) (Figure S11). In both structures the solvent molecules are disordered in a 1:1 ratio across a crystallographic inversion centre. The copper atoms have distorted tetrahedral geometry, being ligated with two phosphorus atoms of dppm ligands and two hydrogen atoms from tetrahydroborate; the selected bond distances and angles are presented in Table 3 (for additional details see Tables S2 and S4). Copper atoms and ligands form eight-member cycles $\mathrm{Cu}_{2} \mathrm{P}_{4} \mathrm{C}_{2}$ that have Twisted Boat-Boat conformation in $\mathbf{1}$ and Boat-Boat conformation in 2 (Figure S11). The $\mathrm{Cu}(1)-\mathrm{Cu}(2)$ distance is 3.2035(4) $\AA$ for $\mathbf{1}$ and 3.392(1) $\AA$ for 2, which is above the sum of van der Waals radii for copper $(2.8 \AA)$, and is within the range (2.679-4.797 $\AA$ ) determined for eight-member $\mathrm{Cu}_{2} \mathrm{P}_{4} \mathrm{C}_{2}$ cycles (Table $\mathrm{S1}$ ).

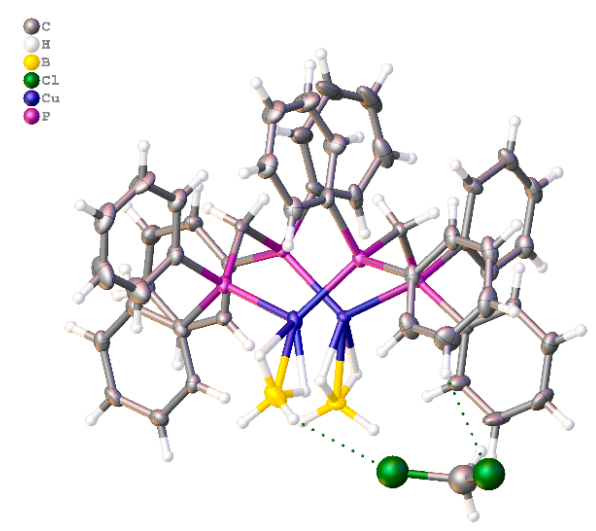

(a)

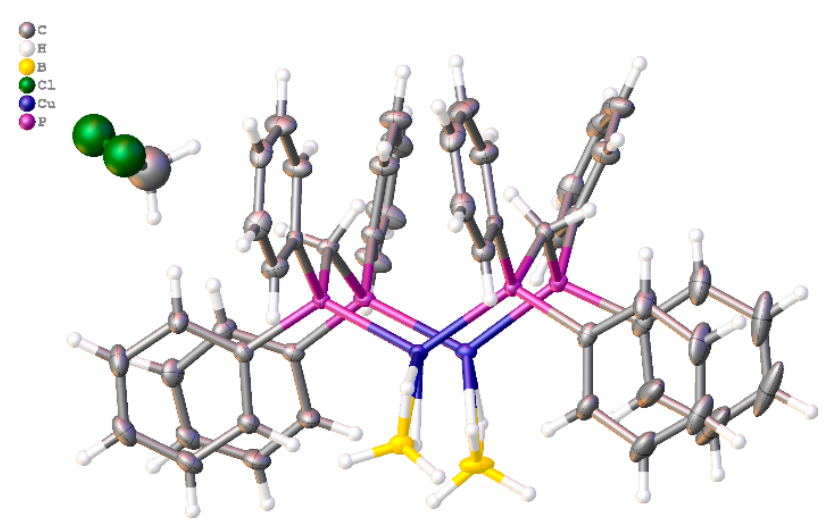

(b)

Figure 1. General view of molecular structures 1 (a) and 2 (b). Thermal ellipsoids are drawn at the 50\% probability level.

The DFT calculations (see below) of 2 revealed its possible structural instability, during the optimization the conformation changes from Boat-Boat to Twist Boat-Boat. 


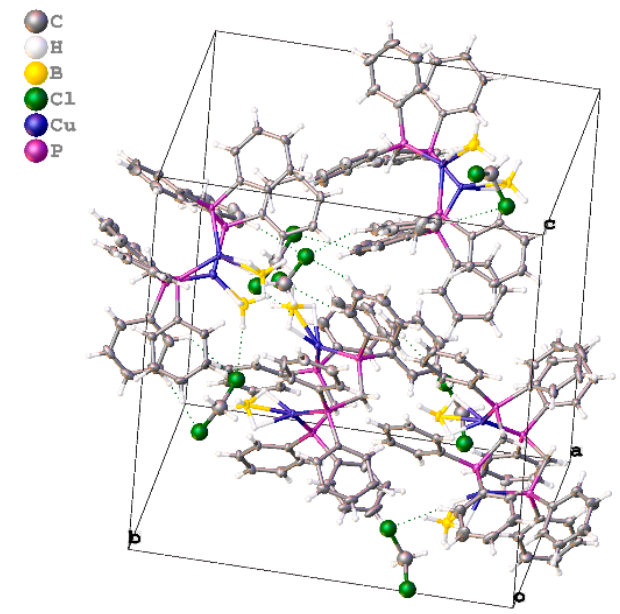

(a)

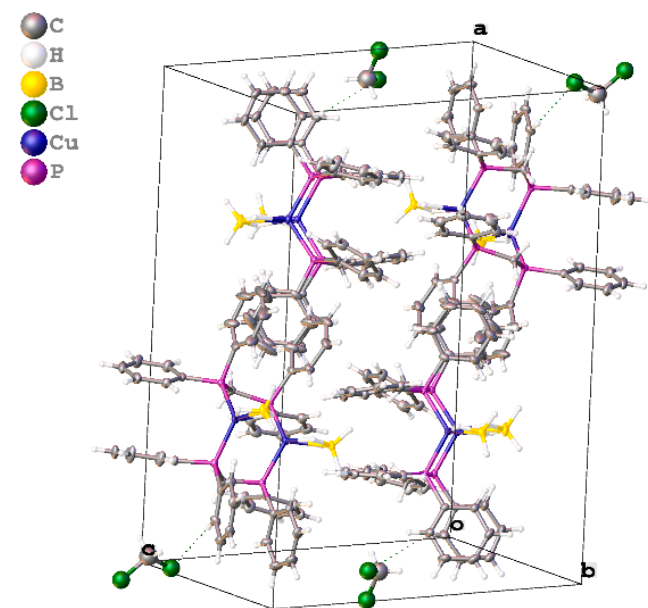

(b)

Figure 2. View of molecular packing of $\mathbf{1}\left(\mathrm{P} 2{ }_{1} 2_{1} 2_{1}\right)(\mathbf{a})$ and $\mathbf{2}\left(\mathrm{P} 2_{1} / \mathrm{c}\right)(\mathbf{b})$ in a unit cell.

Table 3. Selected structural parameters for $\mathbf{1}$ and $\mathbf{2}$.

\begin{tabular}{|c|c|c|c|}
\hline Distances, $\AA$ & 1 & Distances, Å & 2 \\
\hline $\mathrm{Cu}(1) \cdots \mathrm{Cu}(2)$ & $3.392(1)$ & $\mathrm{Cu}(1)-\mathrm{Cu}(2)$ & $3.2035(4)$ \\
\hline $\mathrm{Cu}(1)-\mathrm{P}(2)$ & $2.238(2)$ & $\mathrm{Cu}(1)-\mathrm{P}(2)$ & $2.2234(7)$ \\
\hline $\mathrm{Cu}(2)-\mathrm{P}(1)$ & $2.253(2)$ & $\mathrm{Cu}(2)-\mathrm{P}(1)$ & $2.2608(7)$ \\
\hline $\mathrm{Cu}(1)-\mathrm{P}(3)$ & $2.254(2)$ & $\mathrm{Cu}(1)-\mathrm{P}(3)$ & $2.2288(6)$ \\
\hline $\mathrm{Cu}(2)-\mathrm{P}(4)$ & $2.257(2)$ & $\mathrm{Cu}(2)-\mathrm{P}(4)$ & $2.2542(6)$ \\
\hline $\mathrm{Cu}(1)-\mathrm{B}(1)$ & $2.194(9)$ & $\mathrm{Cu}(1)-\mathrm{B}(1)$ & $2.198(2)$ \\
\hline $\mathrm{Cu}(2)-\mathrm{B}(2)$ & $2.190(7)$ & $\mathrm{Cu}(2)-\mathrm{B}(2)$ & $2.192(3)$ \\
\hline $\mathrm{H}(19) \mathrm{A} \cdots \mathrm{Cl}\left(1^{\prime}\right)$ & 2.722 & $\mathrm{H}(10) \mathrm{A} \cdots \mathrm{Cl}(2) \mathrm{D}$ & 3.031 \\
\hline $\mathrm{H}(13) \mathrm{A} \cdots \mathrm{Cl}\left(1^{\prime}\right)$ & 2.727 & & \\
\hline $\mathrm{H}(29) \mathrm{A} \cdots \mathrm{Cl}\left(1^{\prime}\right)$ & 2.816 & & \\
\hline $\mathrm{H}(28) \mathrm{A} \cdots \mathrm{Cl}\left(1^{\prime}\right)$ & 2.627 & & \\
\hline $\mathrm{H}(1) \mathrm{BD} \cdots \mathrm{Cl}\left(2^{\prime}\right)$ & 2.814 & $\mathrm{H}(26) \mathrm{A} \cdots \mathrm{H}(1) \mathrm{BD}$ & 2.246 \\
\hline Angles, ${ }^{\circ}$ & 1 & Angles, ${ }^{\circ}$ & 2 \\
\hline $\mathrm{P}(2)-\mathrm{Cu}(1)-\mathrm{P}(3)$ & $112.93(7)$ & $\mathrm{P}(2)-\mathrm{Cu}(1)-\mathrm{P}(3)$ & $117.74(2)$ \\
\hline $\mathrm{P}(1)-\mathrm{Cu}(2)-\mathrm{P}(4)$ & 111.33(6) & $\mathrm{P}(1)-\mathrm{Cu}(2)-\mathrm{P}(4)$ & $117.29(2)$ \\
\hline $\mathrm{P}(1)-\mathrm{C}(1)-\mathrm{P}(2)$ & $112.6(3)$ & $\mathrm{P}(1)-\mathrm{C}(1)-\mathrm{P}(2)$ & $110.6(1)$ \\
\hline$P(3)-C(2)-P(4)$ & $109.9(4)$ & $P(3)-C(2)-P(4)$ & $111.5(1)$ \\
\hline $\mathrm{C}(19)-\mathrm{H}(19) \mathrm{A} \cdots \mathrm{Cl}\left(1^{\prime}\right)$ & 150.9 & $\mathrm{C}(10)-\mathrm{H}(10) \mathrm{A} \cdots \mathrm{Cl}(2) \mathrm{D}$ & 149.2 \\
\hline $\mathrm{C}(13)-\mathrm{H}(13) \mathrm{A} \cdots \mathrm{Cl}\left(1^{\prime}\right)$ & 140.8 & & \\
\hline $\mathrm{C}(29)-\mathrm{H}(29) \mathrm{A} \cdots \mathrm{Cl}\left(1^{\prime}\right)$ & 136.0 & & \\
\hline $\mathrm{C}(28)-\mathrm{H}(28) \mathrm{A} \cdots \mathrm{Cl}\left(1^{\prime}\right)$ & 150.4 & & \\
\hline $\mathrm{B}(1)-\mathrm{H}(1) \mathrm{BD} \cdots \mathrm{Cl}\left(2^{\prime}\right)$ & 142.6 & $\mathrm{C}(26)-\mathrm{H}(26) \mathrm{A} \cdots \mathrm{H}(1) \mathrm{BD}$ & 168.2 \\
\hline Dihedral Angles, ${ }^{\circ}$ & 1 & Dihedral Angles, $^{\circ}$ & 2 \\
\hline$\chi_{1}(\mathrm{P}, \mathrm{Cu}, \mathrm{Cu}, \mathrm{P})$ & $-92.41(6)$ & $\chi_{1}(\mathrm{P}, \mathrm{Cu}, \mathrm{Cu}, \mathrm{P})$ & $117.04(2)$ \\
\hline $\mathrm{x}_{2}(\mathrm{P}, \mathrm{Cu}, \mathrm{Cu}, \mathrm{P})$ & $133.69(6)$ & $\mathrm{x}_{2}(\mathrm{P}, \mathrm{Cu}, \mathrm{Cu}, \mathrm{P})$ & $-118.44(2)$ \\
\hline
\end{tabular}

The non-covalent interactions apparently play an important role in the stabilization of both structures. In both crystals the $\pi-\pi$ stacking interaction between the pairs of phenyl rings of dppm ligands is suggested by short inter-ring distance (3.723 $\AA$ for $\mathbf{1}$ and $3.888 \AA$ for 2 ). The analysis of molecular packing of $\mathbf{1}$ (Figure 2a) reveals four short contacts between the $\mathrm{C}-\mathrm{H}$ of phenyl rings of dppm ligands and the chlorine atom of DCM $(\mathrm{C}-\mathrm{H} \cdots \mathrm{Cl})$ per unit cell, which can be considered as weak hydrogen bonds. The angles $(\angle \mathrm{C}-\mathrm{H} \cdots \mathrm{Cl})$ for these interactions vary from 145.9 to $149.6^{\circ}$ and $\mathrm{H} \cdots \mathrm{Cl}$ distances are in the range 2.659-2.679 $\AA$ that is less than the sum of van der Waals radii for 
these two atoms $(2.95 \AA)$. There is also a short $\mathrm{B}-\mathrm{H} \cdots \mathrm{Cl}-\mathrm{C}$ distance $2.755 \AA$ A between $\mathrm{BH}$ and DCM with angle $\angle \mathrm{C}-\mathrm{Cl} \cdots \mathrm{H}(\mathrm{B})=158.2^{\circ}$ that resembles a halogen bonding $[106,107]$ and was referred to as a hydride-halogen bond [108-113]. This interaction has a donor-acceptor nature, where $\mathrm{B}-\mathrm{H}^{\delta-}$ acts as a donor of electron density and interacts with an electron deficient area ( $\sigma$-hole) located on the halogen atom ${ }^{+\delta} \mathrm{Hal}-\mathrm{R}$.

The $\left[\left(\mu_{2}-\mathrm{dppm}\right)_{2} \mathrm{Cu}_{2}\right]\left[\eta^{2}-\mathrm{BH}_{4}\right]_{2}$ molecules in 2 are connected with each other and with the DCM molecules via hydrogen bonds $\left[\mathrm{r}_{(\mathrm{H} \cdots \mathrm{Cl})}=3.031 \AA, \angle \mathrm{C}-\mathrm{H} \cdots \mathrm{Cl}=149.2^{\circ}\right]$ and dihydrogen bonds $\left[\mathrm{r}_{(\mathrm{H} \cdots \mathrm{H})}=2.246 \AA, \angle \mathrm{C}-\mathrm{H} \cdots \mathrm{H}(\mathrm{B})=168.2^{\circ}\right]$ leading to the formation of a two-dimensional network (Figure 2b).

As mentioned above, the borohydride ligand is coordinated to copper via two hydrogen atoms, the distances $\mathrm{Cu} \cdots \mathrm{B}(2.190-2.198 \AA)$ are typical for structures of $\left\{\mathrm{Cu}\left(\eta^{2}-\mathrm{BH}_{4}\right)\right\}$ complexes (according to previously suggested structural criteria) [63] found in CCDC (Table S6), but are slightly shorter if compared with the value $2.212 \AA$ found for $\left(\mathrm{PPh}_{3}\right)_{2} \mathrm{Cu}\left(\eta^{2}-\mathrm{BH}_{4}\right)$ [67]. The $\left\{\mathrm{Cu}\left(\eta^{1}-\mathrm{BH}_{4}\right)\right\}$ complexes are characterized by longer $\mathrm{Cu} \cdots \mathrm{B}$ distances of $2.441-2.499 \AA$.

\subsection{CCDC Analysis}

The CCDC search for the structures containing eight-membered $\left[\left(\mu^{2}-\mathrm{dppm}\right)_{2} \mathrm{Cu}_{2}\right]^{2+}$ moieties gave 110 entries, but none of them bears a $\mathrm{BH}_{4}$ ligand. The crystal structures found are gathered in Table S1, subdivided according to their conformation type (Figure 3) and arranged in ascending order of $\mathrm{Cu}(1) \cdots \mathrm{Cu}(2)$ distances. Eight of the structures found are characterized by strong copper-copper interaction, the $\mathrm{Cu}(1) \cdots \mathrm{Cu}(2)$ distances being less than the sum of van der Waals radii for two $\mathrm{Cu}$ atoms 2.679-2.789 A. For each conformation (Figure 3) we detected the most representative structure among the entries found and the boundary conditions. According to the boundary conditions for basic conformation types (Boat-Boat, Boat-Chair, Chair-Chair and Plain) the difference between two angles $\angle \mathrm{PCuP}$ and between two dihedral angles $\chi(\mathrm{P}, \mathrm{Cu}, \mathrm{Cu}, \mathrm{P})$ should be less or equal $5^{\circ}$. The Chair-Chair conformation is characterized by two straight dihedral angle $\chi(\mathrm{P}, \mathrm{Cu}, \mathrm{Cu}, \mathrm{P})$. Twist-type conformations (Twisted Boat-Boat and Twisted Boat-Chair) should have one dihedral angle $\chi(\mathrm{P}, \mathrm{Cu}, \mathrm{Cu}, \mathrm{P})$ close to $90^{\circ}$ and another obtuse dihedral angle $\chi(\mathrm{P}, \mathrm{Cu}, \mathrm{Cu}, \mathrm{P})\left(>117^{\circ}\right)$. Remaining structures that have geometrical parameters between basic and twisted conformation types were named as distorted conformations (Distorted Boat-Boat and Distorted Boat-Chair). All conformational data are summarized in Table 4 and Table S1.
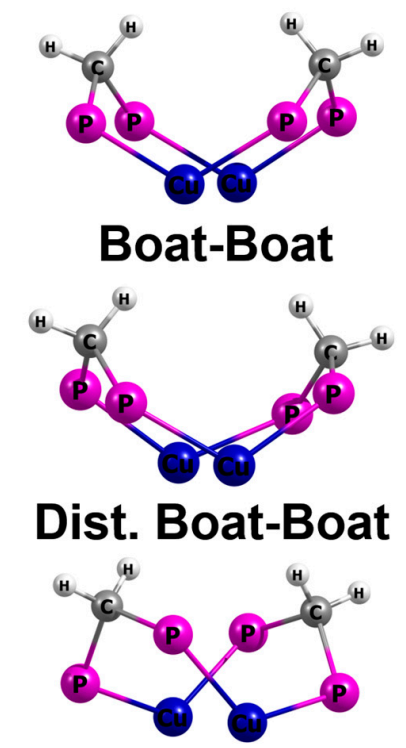

Twisted Boat-Boat

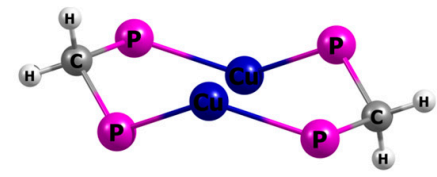

Chair-Chair

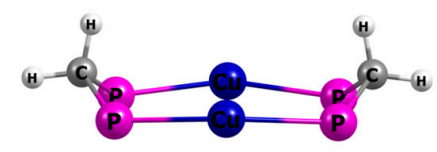

Plain

Figure 3. The conformation types found from CCDC search for $\left[\left(\mu^{2}-\mathrm{dppm}\right)_{2} \mathrm{Cu}_{2}\right]^{2+}$ moieties. 
The analysis reveals that Boat-Boat and Distorted Boat-Boat conformations account for $48 \%$ of all found structures (Figure 4). Other conformation types are Chair-Chair-19\%, Boat-Chair-14\% and Twisted Boat-Boat, comprising 10\% of conformations. The rest of the conformation types (Distorted Boat-Chair, Twisted Boat-Chair and Plain) account for 5\% and less.

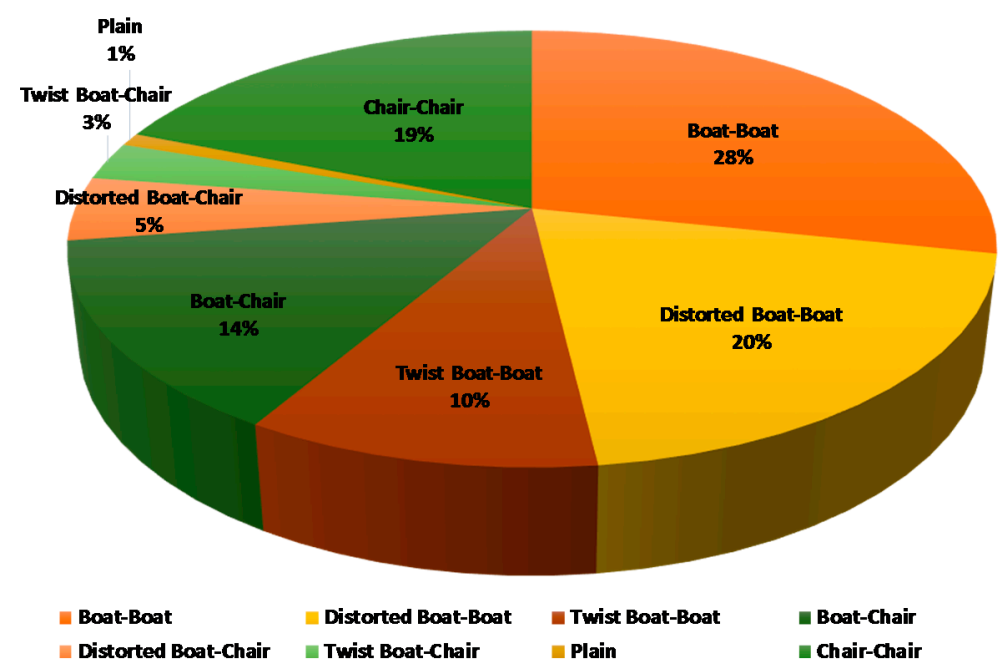

Figure 4. Conformational distribution of eight-membered $\left[\left(\mu^{2}-\mathrm{dppm}\right)_{2} \mathrm{Cu}_{2}\right]^{2+}$ moieties.

The majority of all three Boat-Boat structures (basic, distorted, and twisted) contains a bridging ligand $\left(\mu-\mathrm{R}_{2} \mathrm{~S} ; \mu-\mathrm{R}_{2} \mathrm{CO} ; \mathrm{RPy}-\mathrm{O} ; \mu-\mathrm{NO}_{3} ; \mu-\mathrm{RCOO}\right)$ and is characterized by rather short $\mathrm{Cu}(1) \cdots \mathrm{Cu}(2)$ distances (2.679-3.852 ̊). The Chair-Chair and Plain conformations feature the longest $\mathrm{Cu}(1) \cdots \mathrm{Cu}(2)$ distance (3.359-4.797 $\AA$ ) because these complexes contain chelating or strongly-coordinating ligands, such as bipyridine, pyrazine, phenantroline, and their derivatives. Despite the difference in the solid state conformations, the ${ }^{31} \mathrm{P}$ NMR chemical shifts of dppm ligand in eight-membered $\left[\left(\mu^{2}-\mathrm{dppm}\right)_{2} \mathrm{Cu}_{2}\right]^{2+}$ moieties fall in the same, rather broad, range that does not allow discriminating of the conformation types on the basis of ${ }^{31} \mathrm{P}$ NMR data in solution.

Table 4. Summary of $\mathrm{Cu}(1) \cdots \mathrm{Cu}(2)$ distances, $\mathrm{PCuP}$ and dihedral $\chi(\mathrm{P}, \mathrm{Cu}, \mathrm{Cu}, \mathrm{P})$ angles reported for eight-membered $\left[\left(\mu^{2}-\mathrm{dppm}\right)_{2} \mathrm{Cu}_{2}\right]^{2+}$ moieties. $\mathrm{N}$-number of CCSD structures of certain conformation.

\begin{tabular}{|c|c|c|c|c|c|c|}
\hline Conformation & $\mathbf{N}$ & $\mathrm{d}_{[\mathrm{Cu}(1) \cdots \mathrm{Cu}(2)]}, \AA$ & $\angle \mathrm{PCuP}^{\prime},^{\circ}$ & $\mathrm{X}_{\left[\mathrm{P}, \mathrm{Cu}(1), \mathrm{Cu}(2), \mathrm{P}^{\prime}\right]},^{\circ}$ & $\angle \mathrm{PCHP}^{\prime}{ }^{\circ}$ & $\delta^{31} \mathbf{P}\left\{{ }^{1} \mathrm{H}\right\}, \mathrm{ppm}$ \\
\hline Boat-Boat & 30 & $2.679-3.651$ & $113-136$ & $113-136$ & $110-117$ & $-7.8 \div-15.2$ \\
\hline $\begin{array}{l}\text { Distorted } \\
\text { Boat-Boat }\end{array}$ & 21 & $2.931-3.852$ & $95-133$ & 87-115/117-139 & $111-117$ & $-7.9 \div-25.7$ \\
\hline $\begin{array}{c}\text { Twist } \\
\text { Boat-Boat }\end{array}$ & 11 & $2.743-3.757$ & $110-140$ & 89-103/134-164 & 109-115 & $+2.1 \div-14.6$ \\
\hline Boat-Chair & 15 & $2.735-3.901$ & $117-133$ & $119-138$ & $111-116$ & $-6.3 \div-10.9$ \\
\hline $\begin{array}{c}\text { Distorted } \\
\text { Boat-Chair }\end{array}$ & 5 & $2.712-4.644$ & $115-146$ & $113-171$ & $110-122$ & $-6.6 \div-18.7$ \\
\hline $\begin{array}{c}\text { Twist } \\
\text { Boat-Chair }\end{array}$ & 3 & $2.925 / 3.133$ & $120-122 / 130-132$ & 105-108/145-148 & $110-115$ & $-7.7 /-8.2$ \\
\hline Plain & 1 & 4.277 & $148 / 150$ & 170 & 117 & - \\
\hline Chair-Chair & 20 & $3.359-4.797$ & $130-145$ & $179-180$ & $110-147$ & $-5.6 \div-14.4$ \\
\hline
\end{tabular}

\subsection{DFT Calculations}

Since our attempt to synthesize the monomeric compound $\left(\eta^{2}-\mathrm{dppm}\right) \mathrm{Cu}\left(\eta^{2}-\mathrm{BH}_{4}\right)($ Figure 5a), previously described in [71] has failed, we attempted to optimize this structure by different DFT methods. However, these attempts were unsuccessful; instead of the proposed structure (Figure 5a), they gave the $\left(\eta^{1}-\mathrm{dppm}\right) \mathrm{Cu}\left(\eta^{2}-\mathrm{BH}_{4}\right)$ complex stabilized by copper interaction with a phenyl ring 
(Figure $5 b)$. The formation of the $\left[\left(\mu_{2}-\mathrm{dppm}\right)_{2} \mathrm{Cu}_{2}\right]\left[\eta^{2}-\mathrm{BH}_{4}\right]_{2}$ dimer from two molecules of monomeric $\left(\eta^{1}-\mathrm{dppm}\right) \mathrm{Cu}\left(\eta^{2}-\mathrm{BH}_{4}\right)$ is energetically favourable, $\Delta \mathrm{G}_{\mathrm{DCM}}{ }^{\circ}$ form being $-19.3 \mathrm{kcal} / \mathrm{mol}(\mathrm{M} 06)$ and $-24.0 \mathrm{kcal} / \mathrm{mol}$ (B3LYP-D2) (Table S5). This is in agreement with only a few examples of $\mathrm{Cu}(\mathrm{I})$ complexes reported in which dppm acts as a chelate ligand $\left(\eta^{2}-\mathrm{dppm}\right.$, Scheme 1) [114]; the dinuclear $\mathrm{Cu}(\mathrm{I})$ complexes with two bridging dppm ligands are by far more common [115].

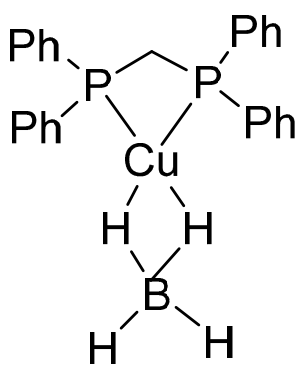

(a)

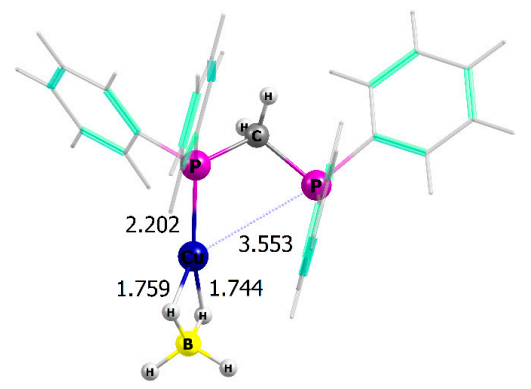

(b)

Figure 5. The tentative structure of $\left(\eta^{2}-\mathrm{dppm}\right) \mathrm{Cu}\left(\eta^{2}-\mathrm{BH}_{4}\right)$ monomer (a) and its M06-optimized geometry (b).

The geometry optimizations by M06 and B3LYP-D2 methods (Table S7) reproduced quite well the $\mathrm{X}$-ray determined geometry 1 of the binuclear copper complex; the difference between the calculated and experimentally determined $\mathrm{Cu}(1) \cdots \mathrm{Cu}(2)$ distances $(0.006 \AA$ for M06 and $0.155 \AA$ for B3LYP-D2) is the lowest among other DFT functionals used (Tables S2 and S3). The difference between the calculated and experimentally observed $\mathrm{Cu}-\mathrm{P}$ bonds lengths is also rather small, $0.039-0.020 \AA$ (M06) and less than $0.020 \AA$ for B3LYP-D2. The difference in experimental and theoretical $\mathrm{CuH}$ bond length and $\mathrm{Cu} \cdots \mathrm{B}$

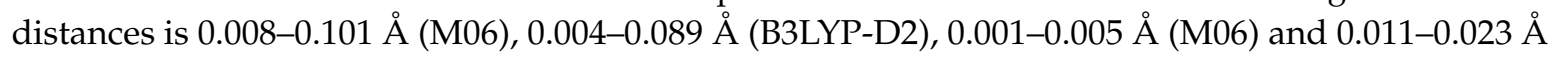
(B3LYP-D2), respectively. The analogous performance for M06 and B3LYP-D2 methods was previously observed for calculations of the $\mathrm{Cu}$ (II)-silsesquioxane core [116]. When the optimization was attempted for the geometry of structure 2, it led to the conformation changes converting from Boat-Boat to Twisted Boat-Boat. No local minimum was found for the Boat-Boat conformation type.

The simulated IR spectra of $\mathbf{1}$ (Twisted Boat-Boat) optimized by M06 and B3LYP-D2 methods are in line with the experimental IR spectra of $\left[\left(\mu_{2}-\mathrm{dppm}\right)_{2} \mathrm{Cu}_{2}\right]\left[\eta^{2}-\mathrm{BH}_{4}\right]_{2}$ in $\mathrm{KBr}$ pellets (Figure 6, Table 5). The M06 and B3LYP-D2-optimized $\left(\eta^{1}-\mathrm{dppm}\right) \mathrm{Cu}\left(\eta^{2}-\mathrm{BH}_{4}\right)$ monomer gives similar positions of IR-active stretching vibrations but has a significant difference in the relative IR intensity of $\mathrm{BH}_{\text {term }}$ stretching vibrations.

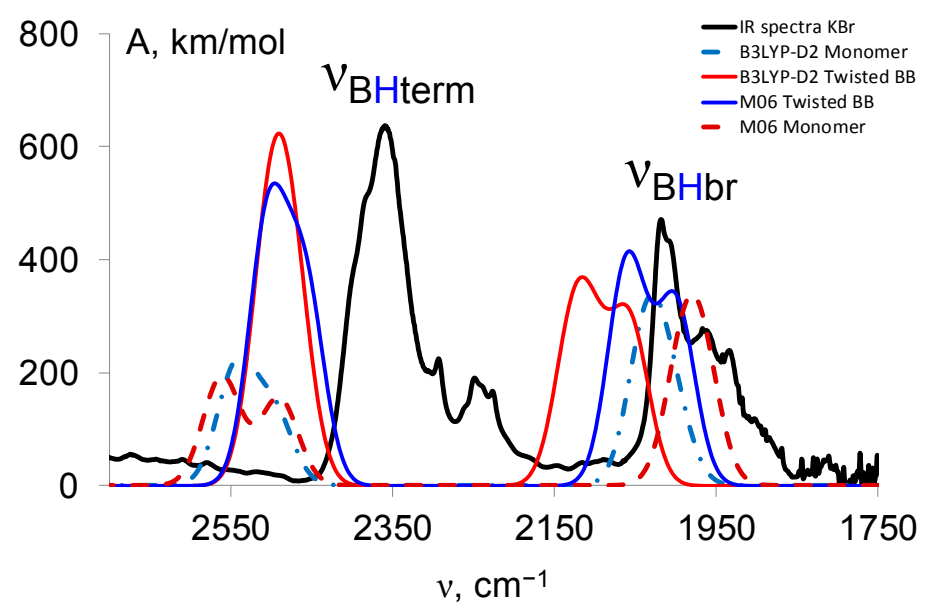

Figure 6. Experimental IR spectra of $\left[\left(\mu_{2}-\mathrm{dppm}\right)_{2} \mathrm{Cu}_{2}\right]\left[\eta^{2}-\mathrm{BH}_{4}\right]_{2}$ and simulated IR spectra of M06 and B3LYP-D2 optimized $\left(\eta^{1}-\mathrm{dppm}\right) \mathrm{Cu}\left(\eta^{2}-\mathrm{BH}_{4}\right)$ monomer and $\mathbf{1}$. No scaling factors applied. 
Table 5. Experimental and the calculated values of IR-active vibration bands for crystal structure $\mathbf{1}$ and optimized structures.

\begin{tabular}{|c|c|c|c|c|c|}
\hline \multirow[b]{2}{*}{ Vibration type } & \multicolumn{3}{|c|}{1} & \multicolumn{2}{|c|}{ Monomer } \\
\hline & expt & M06 & B3LYP-GD2 & M06 & B3LYP-GD2 \\
\hline$v_{\mathrm{CH}}{ }^{\text {as }}(\mathrm{Ph})$ & 3075,3049 & 3228,3225 & 3230,3220 & 3229,3227 & 3228,3218 \\
\hline$v_{\mathrm{CH}}{ }^{a s}(\mathrm{CH} 2)$ & - & 3109,3024 & 3053,3046 & 3058 & 3179 \\
\hline$v_{\text {BHterm }}{ }^{\text {as }}$ & 2382 & 2504 & 2507 & 2561 & 2543 \\
\hline$v_{\text {BHterm }} \mathrm{s}$ & 2360 & 2459 & 2493 & 2490 & 2497 \\
\hline$v_{\mathrm{BHbr} 1}$ as & 2019 & 2061 & 2127,2101 & 1991 & 2035 \\
\hline$v_{\mathrm{BHbr} 2}{ }^{\text {as }}$ & 1967 & 2000 & 2057 & 1968 & 2004 \\
\hline$v_{\mathrm{CuH}}$ & 1433,1384 & 1421,1412 & 1417,1396 & 1453 & 1444 \\
\hline$\delta_{\mathrm{BH}}$ & 1133 & 1165 & 1187,1178 & 1147 & 1168 \\
\hline$v_{\mathrm{CuB}}$ & 358 & 405 & 392 & 357 & 362 \\
\hline
\end{tabular}

\section{Summary and Conclusions}

The XRD analysis of monocrystals revealed the first example of the bimetallic complex $\left[\left(\mu_{2} \text {-dppm }\right)_{2} \mathrm{Cu}_{2}\right]\left[\eta^{2}-\mathrm{BH}_{4}\right]_{2}$ bearing two dppm ligands bridging two $\left\{\mathrm{Cu}\left(\eta^{2}-\mathrm{BH}_{4}\right)\right\}$ fragments. Two solvatomorphic structures were identified: one of orthorhombic space group $\mathrm{P} 2{ }_{1} 2_{1} 2_{1}$ with one DCM molecule 1 and the second one of monoclinic space group $P 2_{1} / c$ with $\frac{1}{2}$ molecule of DCM per molecule of complex 2 . The former structure possesses the twisted boat-boat conformation, which is rather rare for eight-membered $\left[\left(\mu^{2}-\mathrm{dppm}\right){ }_{2} \mathrm{Cu}_{2}\right]^{2+}$ moieties. Analysis of the literature data revealed that, despite the difference in conformations, the ${ }^{31} \mathrm{P}$ NMR chemical shift of dppm ligand in eight-membered $\left[\left(\mu^{2} \text {-dppm }\right)_{2} \mathrm{Cu}_{2}\right]^{2+}$ moieties does not enable identification of conformation type in solution. On the other hand, the ${ }^{11} \mathrm{~B}$ NMR and IR spectra could be used to discriminate between the $\eta^{1}$ and $\eta^{2}-\mathrm{BH}_{4}$ coordination modes. However, the final assignment should come from the XRD analysis.

The DFT calculations by M06 and B3LYP-D2 methods reproduced, quite well, the geometry of 1 and observed experimental IR spectra. Optimization of 2 revealed structural instability during the optimization conformation changes from Boat-Boat to Twisted Boat-Boat (Table S4). This finding is surprising because Boat-Boat and Distorted Boat-Boat conformations account, together, for $48 \%$ of the reported CCSD structures bearing eight-membered $\left[\left(\mu^{2}-\mathrm{dppm}\right)_{2} \mathrm{Cu}_{2}\right]^{2+}$ fragments, whereas the Twisted Boat-Boat conformation is revealed only for $10 \%$ of compounds.

Supplementary Materials: The following are available online at www.mdpi.com/2073-4352/7/10/318/s1. Figure S1. ${ }^{1} \mathrm{H}$ NMR spectra $\left(500 \mathrm{MHz}, \mathrm{CD}_{2} \mathrm{Cl}_{2}, 298 \mathrm{~K}\right.$, ppm) of $\left[\left(\mu_{2}-\mathrm{dppm}\right)_{2} \mathrm{Cu}_{2}\right]\left[\eta^{2}-\mathrm{BH}_{4}\right]_{2}$. Figure S2. ${ }^{11} \mathrm{~B}\left\{{ }^{1} \mathrm{H}\right\}$ NMR spectra $\left(160 \mathrm{MHz}, \mathrm{CD}_{2} \mathrm{Cl}_{2}, 298 \mathrm{~K}\right.$, ppm) of $\left[\left(\mu_{2}-\mathrm{dppm}\right)_{2} \mathrm{Cu}_{2}\right]\left[\eta^{2}-\mathrm{BH}_{4}\right]_{2}$. Figure $\mathrm{S} 3 .{ }^{31} \mathrm{P}\left\{{ }^{1} \mathrm{H}\right\}$ NMR spectra $\left(202 \mathrm{MHz}, \mathrm{CD}_{2} \mathrm{Cl}_{2}, 298 \mathrm{~K}\right.$, ppm) of $\left[\left(\mu_{2}-\mathrm{dppm}\right){ }_{2} \mathrm{Cu}_{2}\right]\left[\eta^{2}-\mathrm{BH}_{4}\right]_{2}$. Figure S4. ${ }^{13} \mathrm{C}\left\{{ }^{1} \mathrm{H}\right\} \mathrm{NMR}$ spectra $\left(126 \mathrm{MHz}, \mathrm{CD}_{2} \mathrm{Cl}_{2}, 298 \mathrm{~K}\right.$, ppm) of $\left[\left(\mu_{2}-\mathrm{dppm}\right)_{2} \mathrm{Cu}_{2}\right]\left[\eta^{2}-\mathrm{BH}_{4}\right]_{2}$. Figure S5. ${ }^{13} \mathrm{C}\left\{{ }^{1} \mathrm{H}\right\} \mathrm{NMR}$ spectra $(126 \mathrm{MHz}$, $\left.\mathrm{CD}_{2} \mathrm{Cl}_{2}, 298 \mathrm{~K}, \mathrm{ppm}\right)$ of $\left[\left(\mu_{2}-\mathrm{dppm}\right)_{2} \mathrm{Cu}_{2}\right]\left[\eta^{2}-\mathrm{BH}_{4}\right]_{2}(16,850-16,600 \mathrm{~Hz})$. Figure S6. ${ }^{13} \mathrm{C}\left\{{ }^{1} \mathrm{H}\right\} \mathrm{NMR}$ spectra $\left(126 \mathrm{MHz}, \mathrm{CD}_{2} \mathrm{Cl}_{2}, 298 \mathrm{~K}\right.$, ppm) of $\left[\left(\mu_{2}-\mathrm{dppm}\right)_{2} \mathrm{Cu}_{2}\right]\left[\eta^{2}-\mathrm{BH}_{4}\right]_{2}(3290-3180 \mathrm{~Hz})$. Figure S7. $\left.{ }^{13} \mathrm{Cl}_{1}{ }^{1} \mathrm{H}\right\} \mathrm{NMR}$ spectra $\left(126 \mathrm{MHz}, \mathrm{CD}_{2} \mathrm{Cl}_{2}, 298 \mathrm{~K}, \mathrm{ppm}\right)$ in JMODECHO mode of $\left[\left(\mu_{2}-\mathrm{dppm}\right)_{2} \mathrm{Cu}_{2}\right]\left[\eta^{2}-\mathrm{BH}_{4}\right]_{2}$. Figure S8. FTIR spectra of $\left[\left(\mu_{2}-\mathrm{dppm}\right)_{2} \mathrm{Cu}_{2}\right]\left[\eta^{2}-\mathrm{BH}_{4}\right]_{2}$ in $\mathrm{KBr}$ pellet. Figure S9. FTIR spectra of $\left[\left(\mu_{2}-\mathrm{dppm}\right)_{2} \mathrm{Cu}_{2}\right]\left[\eta^{2}-\mathrm{BH}_{4}\right]_{2}$ in Nujol mull/thin polyethylene film. Figure S10. ${ }^{31} \mathrm{P}\{1 \mathrm{H}\}\left(202 \mathrm{MHz}, 298 \mathrm{~K}\right.$, ppm) and ${ }^{1} \mathrm{H}$ NMR spectra $(500 \mathrm{MHz}$, $298 \mathrm{~K}, \mathrm{ppm})$ of $\left[\left(\mu_{2}-\mathrm{dppm}\right)_{2} \mathrm{Cu}_{2}\right]\left[\eta^{2}-\mathrm{BH}_{4}\right]_{2}$ in $\mathrm{CDCl}_{3}$. Figure S11. General view of molecular structures of $\mathbf{1}$ and 2 conformations. The solvents molecules are omitted for clarity. Table S1. CCDC analysis of the structures, containing eight-membered $\left[\left(\mu_{2}-\mathrm{dppm}\right)_{2} \mathrm{Cu}_{2}\right]^{2+}$ moieties. Table S2. Structural parameters of crystal structure $\mathbf{1}$ (Twisted Boat-Boat) and optimized structures. Table S3. The differences between structural parameters of crystal structure 1 (Twisted Boat-Boat) and optimized structures. Table S4. Structural parameters of crystal structure 2 (Boat-Boat) and optimized structures. Table S5. Energy of formation of DFT-optimized geometries binuclear complexes (1 and $\mathbf{2}$ ) computed relative monomer complexes. Table S6. CCDC analysis of the structures, containing $\left\{\mathrm{Cu}\left(\mathrm{BH}_{4}\right)\right\}$ moieties. Table S7. DFT-optimised geometries (Cartesian coordinates) and electronic energies.

Acknowledgments: Some parts of our work were financially supported by the Ministry of Education and Science of the Russian Federation (the Agreement number 02.a03.21.0008), the Russian-Italian bilateral project CNR-RFBR no. 15-53-78027 and RFBR project no. 16-03-00324. The X-ray diffraction and NMR spectroscopic data were obtained using the equipment of Centre for Molecule Composition Studies of INEOS RAS. 
Author Contributions: Evgenii I. Gutsul and Andrea Rossin carried out the synthesis. Konstantin A. Lyssenko performed the XRD experiments. Alexander S. Peregudov measured NMR experiments. Evgenii I. Gutsul conducted the FTIR investigation. Viktor D. Makhaev contributed reagents. Lina M. Epstein analysed the literature data. Igor E. Golub and Oleg A. Filippov performed the DFT calculations. Natalia V. Belkova and Igor E. Golub analysed the data and wrote the paper. Maurizio Peruzzini and Elena S. Shubina conceived experiments and supervised the work.

Conflicts of Interest: The author declare no conflict of interest.

\section{References}

1. Niedner-Schatteburg, G. Cooperative effects in clusters and oligonuclear complexes of transition metals in isolation. In Clusters - Contemporary Insight in Structure and Bonding; Dehnen, S., Ed.; Springer International Publishing: Cham, Switzerland, 2017; pp. 1-40.

2. Chaudret, B.; Delavaux, B.; Poilblanc, R. Bisdiphenylphosphinomethane in dinuclear complexes. Coord. Chem. Rev. 1988, 86, 191-243. [CrossRef]

3. Balakrishna, M.S.; Reddy, V.S.; Krishnamurthy, S.S.; Nixon, J.F.; Laurent, J.C.T.R.B.S. Coordination chemistry of diphosphinoamine and cyclodiphosphazane ligands. Coord. Chem. Rev. 1994, 129, 1-90. [CrossRef]

4. Mague, J.T. "Short-bite” ligands in cluster synthesis. J. Cluster Sci. 1995, 6, 217-269. [CrossRef]

5. Maggini, S. Classification of P,N-binucleating ligands for hetero- and homobimetallic complexes. Coord. Chem. Rev. 2009, 253, 1793-1832. [CrossRef]

6. Naik, S.; Mague, J.T.; Balakrishna, M.S. Short-bite PNP ligand-supported rare tetranuclear $\left[\mathrm{Cu}_{4} \mathrm{I}_{4}\right]$ clusters: Structural and photoluminescence studies. Inorg. Chem. 2014, 53, 3864-3873. [CrossRef] [PubMed]

7. Fliedel, C.; Ghisolfi, A.; Braunstein, P. Functional short-bite ligands: Synthesis, coordination chemistry, and applications of $\mathrm{N}$-functionalized bis(diaryl/dialkylphosphino)amine-type ligands. Chem. Rev. 2016, 116, 9237-9304. [CrossRef] [PubMed]

8. Muetterties, E.L. Metal clusters in catalysis III.-Clusters as models for chemisorption processes and heterogeneous catalysis. Bull. Soc. Chim. Belg. 1975, 84, 959-986. [CrossRef]

9. Muetterties, E.L.; Krause, M.J. Catalysis by molecular metal clusters. Angew. Int. Ed. 1983, 22, 135-148. [CrossRef]

10. Adam, F.I.; Hogarth, G.; Richards, I. Models of the iron-only hydrogenase: Reactions of $\left[\mathrm{Fe}_{2}(\mathrm{CO})_{6}(\mu-\mathrm{pdt})\right]$ with small bite-angle diphosphines yielding bridge and chelate diphosphine complexes $\left[\mathrm{Fe}_{2}(\mathrm{CO})_{4}\right.$ (diphosphine)( $\mu$-pdt)]. J. Organomet. Chem. 2007, 692, 3957-3968. [CrossRef]

11. Adam, F.I.; Hogarth, G.; Kabir, S.E.; Richards, I. Models of the iron-only hydrogenase: Synthesis and protonation of bridge and chelate complexes $\left[\mathrm{Fe}_{2}(\mathrm{CO})_{4}\left\{\mathrm{Ph}_{2} \mathrm{P}\left(\mathrm{CH}_{2}\right) \mathrm{nPPh}{ }_{2}\right\}(\mu-\mathrm{pdt})\right](\mathrm{n}=2-4)$-Evidence for a terminal hydride intermediate. C. R. Chim. 2008, 11, 890-905. [CrossRef]

12. Yen, T.-H.; Chu, K.-T.; Chiu, W.-W.; Chien, Y.-C.; Lee, G.-H.; Chiang, M.-H. Synthesis and characterization of the diiron biomimics bearing phosphine borane for hydrogen formation. Polyhedron 2013, 64, $247-254$. [CrossRef]

13. Isaacs, E.E.; Graham, W.A.G. Phosphorus-31 nuclear magnetic resonance spectra of fac and mer isomers of tricarbonylbis[bis(diphenylphosphino)methane]molybdenum. Inorg. Chem. 1975, 14, 2560-2561. [CrossRef]

14. Cotton, F.A.; Matusz, M. Synthesis, molecular structure and spectroscopic characterization of $\operatorname{Mo}(C O)_{2} I_{2}$ $\left(\eta^{2}-\mathrm{dppm}\right)\left(\eta^{1}-\mathrm{dppm}\right)$. Polyhedron 1987, 6, 261-267. [CrossRef]

15. Gao, Y.; Holah, D.G.; Hughes, A.N.; Spivak, G.J.; Havighurst, M.D.; Magnuson, V.R.; Polyakov, V. Reactions of $\mathrm{Fe}^{\mathrm{III}}$ with $\mathrm{LiAlH}_{4}$ and $\mathrm{LiBH}_{4}$ in the presence of bis(diphenylphosphino)methane (dppm) and CO. The crystal and molecular structures of trans- $\left[\mathrm{Fe}(\mathrm{Cl})(\mathrm{CO})\left(\eta^{2}-\mathrm{dppm}\right)_{2}\right]\left[\mathrm{FeCl}_{4}\right]$, trans- $\mathrm{Fe}(\mathrm{H})_{2}\left(\eta^{2}-\mathrm{dppm}\right)_{2}$ and cis-[Fe $\left(\eta^{2}-\mathrm{S}_{2} \mathrm{CH}\left(\eta^{2}-\mathrm{dppm}\right)_{2}\right] \mathrm{BF}_{4}$. Polyhedron 1997, 16, 2797-2807. [CrossRef]

16. Gandhi, T.; Nethaji, M.; Jagirdar, B.R. Novel double insertion of carbon disulfide into two Ru-H bonds of $\left[(\mathrm{dppm})_{2} \mathrm{Ru}(\mathrm{H})_{2}\right]\left(\mathrm{dppm}=\mathrm{Ph}_{2} \mathrm{PCH}_{2} \mathrm{PPh}_{2}\right)$ : Synthesis and crystal structure of a methanedithiolate complex. Inorg. Chem. 2003, 42, 667-669. [CrossRef] [PubMed]

17. Wilton-Ely, J.D.E.T.; Solanki, D.; Hogarth, G. Synthesis and reactivity of the Ruthenium(II) Dithiocarbonate complex $\left[\mathrm{Ru}\left(\mathrm{k}^{2}-\mathrm{S}_{2} \mathrm{CO}\right)(\mathrm{dppm})_{2}\right](\mathrm{dppm}=$ bis(diphenylphosphino)methane). Inorg. Chem. 2006, 45, 5210-5214. [CrossRef] [PubMed]

18. Puddephatt, R.J. Chemistry of bis(diphenylphosphino)methane. Chem. Soc. Rev. 1983, 12, 99-127. [CrossRef] 
19. Bera, J.K.; Nethaji, M.; Samuelson, A.G. Anion-controlled nuclearity and metal-metal distances in copper(I)-dppm complexes (dppm = Bis(diphenylphosphino)methane). Inorg. Chem. 1999, 38, $218-228$. [CrossRef]

20. Fan, W.-W.; Li, Z.-F.; Li, J.-B.; Yang, Y.-P.; Yuan, Y.; Tang, H.-Q.; Gao, L.-X.; Jin, Q.-H.; Zhang, Z.-W.; Zhang, C.-L. Synthesis, structure, terahertz spectroscopy and luminescent properties of copper (I) complexes with bis(diphenylphosphino)methane and N-donor ligands. J. Mol. Struct. 2015, 1099, 351-358. [CrossRef]

21. El Sayed Moussa, M.; Evariste, S.; Wong, H.L.; Le Bras, L.; Roiland, C.; Le Polles, L.; Le Guennic, B.; Costuas, K.; Yam, V.W.W.; Lescop, C. A solid state highly emissive Cu(I) metallacycle: Promotion of cuprophilic interactions at the excited states. Chem. Commun. 2016, 52, 11370-11373. [CrossRef] [PubMed]

22. He, L.-H.; Luo, Y.-S.; Di, B.-S.; Chen, J.-L.; Ho, C.-L.; Wen, H.-R.; Liu, S.-J.; Wang, J.-Y.; Wong, W.-Y. Luminescent three- and four-coordinate dinuclear copper(i) complexes triply bridged by bis(diphenylphosphino)methane and functionalized 3-(2-Pyridyl)-1,2,4-triazole ligands. Inorg. Chem. 2017, 56, 10311-10324. [CrossRef] [PubMed]

23. Motokura, K.; Kashiwame, D.; Takahashi, N.; Miyaji, A.; Baba, T. Highly active and selective catalysis of copper diphosphine complexes for the transformation of carbon dioxide into silyl formate. Chem. Eur. J. 2013, 19, 10030-10037. [CrossRef] [PubMed]

24. Nakamae, K.; Kure, B.; Nakajima, T.; Ura, Y.; Tanase, T. Facile insertion of carbon dioxide into $\mathrm{Cu}_{2}(\mu-\mathrm{H})$ dinuclear units supported by tetraphosphine ligands. Chem. Asian J. 2014, 9, 3106-3110. [CrossRef] [PubMed]

25. Nakamae, K.; Tanaka, M.; Kure, B.; Nakajima, T.; Ura, Y.; Tanase, T. A fluxional $\mathrm{Cu}_{8} \mathrm{H}_{6}$ cluster supported by bis(diphenylphosphino)methane and its facile reaction with $\mathrm{CO}_{2}$. Chem. Eur. J. 2017, 23, 9457-9461. [CrossRef] [PubMed]

26. Shiu, L.-C.; Liu, S.-A.; Wu, T.-S.; Shiu, K.-B. Synthesis and structures of $d_{10}-d_{10} M_{2}(\mu-d p p m)_{2}$ complexes with sensitive metal-metal distances in response to the binding of sigma donors. J. Chin. Chem. Soc. 2016, 63, 1051-1055. [CrossRef]

27. Bera, J.K.; Nethaji, M.; Samuelson, A.G. Synthesis and structures of oxyanion encapsulated copper(i)-dppm complexes $(\mathrm{dppm}=$ bis(diphenylphosphino)methane). Inorg. Chem. 1999, 38, 1725-1735. [CrossRef] [PubMed]

28. Ahlquist, M.; Fokin, V.V. Enhanced reactivity of dinuclear copper(I) acetylides in dipolar cycloadditions. Organometallics 2007, 26, 4389-4391. [CrossRef]

29. Hein, J.E.; Fokin, V.V. Copper-catalyzed azide-alkyne cycloaddition (CuAAC) and beyond: New reactivity of copper(i) acetylides. Chem. Soc. Rev. 2010, 39, 1302-1315. [CrossRef] [PubMed]

30. Worrell, B.T.; Malik, J.A.; Fokin, V.V. Direct evidence of a dinuclear copper intermediate in Cu(I)-catalyzed azide-alkyne cycloadditions. Science 2013, 340, 457. [CrossRef] [PubMed]

31. Jin, L.; Tolentino, D.R.; Melaimi, M.; Bertrand, G. Isolation of bis(copper) key intermediates in Cu-catalyzed azide-alkyne "click reaction". Sci. Adv. 2015, 1, e1500304. [CrossRef] [PubMed]

32. Singh, D.P.; Allam, B.K.; Singh, K.N.; Singh, V.P. Binuclear Cu(I) complex of (N1E,N2E)-N1,N2bis(phenyl(pyridin-2-yl)methylene)oxalohydrazide: Synthesis, crystal structure and catalytic activity for the synthesis of 1,2,3-triazoles. J. Mol. Catal. A Chem. 2015, 398, 158-163. [CrossRef]

33. Wang, C.; Ikhlef, D.; Kahlal, S.; Saillard, J.-Y.; Astruc, D. Metal-catalyzed azide-alkyne "click" reactions: Mechanistic overview and recent trends. Coord. Chem. Rev. 2016, 316, 1-20. [CrossRef]

34. Zhu, L.; Brassard, C.J.; Zhang, X.; Guha, P.M.; Clark, R.J. On the mechanism of copper(i)-catalyzed azide-alkyne cycloaddition. Chem. Rec. 2016, 16, 1501-1517. [CrossRef] [PubMed]

35. Ziegler, M.S.; Lakshmi, K.V.; Tilley, T.D. Dicopper $\mathrm{Cu}(\mathrm{I}) \mathrm{Cu}(\mathrm{I})$ and $\mathrm{Cu}(\mathrm{I}) \mathrm{Cu}(\mathrm{II})$ complexes in copper-catalyzed azide-alkyne cycloaddition. J. Am. Chem. Soc. 2017, 139, 5378-5386. [CrossRef] [PubMed]

36. Fleet, G.W.J.; Harding, P.J.C. Convenient synthesis of bis(triphenylphosphine) copper(I) tetrahydroborate and reduction of acid chlorides to aldehydes. Tetrahedron Lett. 1979, 20, 975-978. [CrossRef]

37. Fleet, G.W.J.; Harding, P.J.C.; Whitcombe, M.J. Bis(triphenylphosphine)copper (I) tetrahydroborate in the reduction of P-toluenesulphonylhydrazones and 2,4,6-triisopropylbenzenesulphonyl hydrazones (trisyl hdyrazones) to alkanes. Tetrahedron Lett. 1980, 21, 4031-4034. [CrossRef]

38. Sorrell, T.N.; Pearlman, P.S. Preparation of aldehydes from acid chlorides using copper tetrahydroborate complexes. J. Org. Chem. 1980, 45, 3449-3451. [CrossRef]

39. Fleet, G.W.J.; Harding, P.J.C. Selectivity in the acid catalysed reduction of carbonyl compounds to alcohols by bis(triphenylphosphine)copper(I) tetrahydroborate: Reduction of aldehydes in the presence of ketones. Tetrahedron Lett. 1981, 22, 675-678. [CrossRef] 
40. Bhanushali, M.J.; Nandurkar, N.S.; Bhor, M.D.; Bhanage, B.M. Direct reductive amination of carbonyl compounds using bis(triphenylphosphine) copper(I) tetrahydroborate. Tetrahedron Lett. 2007, 48, 1273-1276. [CrossRef]

41. Grutsch, P.A.; Kutal, C. Use of copper(I) phosphine compounds to photosensitize the valence isomerization of norbornadiene. J. Am. Chem. Soc. 1977, 99, 6460-6463. [CrossRef]

42. Grutsch, P.A.; Kutal, C. Photobehavior of copper(I) compounds. Role of copper(I)-phosphine compounds in the photosensitized valence isomerization of norbornadiene. J. Am. Chem. Soc. 1979, 101, 4228-4233. [CrossRef]

43. Liaw, B.; Orchard, S.W.; Kutal, C. Photobehavior of copper(I) compounds. 4. Role of the triplet state of (arylphosphine)copper(I) complexes in the photosensitized isomerization of dienes. Inorg. Chem. 1988, 27, 1311-1316. [CrossRef]

44. Hu, X.; Soleilhavoup, M.; Melaimi, M.; Chu, J.; Bertrand, G. Air-stable (CAAC)CuCl and (CAAC)CuBH complexes as catalysts for the hydrolytic dehydrogenation of $\mathrm{BH}_{3} \mathrm{NH}_{3}$. Angew. Chem. 2015, 127, 6106-6109. [CrossRef]

45. Jepsen, L.H.; Ley, M.B.; Lee, Y.-S.; Cho, Y.W.; Dornheim, M.; Jensen, J.O.; Filinchuk, Y.; Jørgensen, J.E.; Besenbacher, F.; Jensen, T.R. Boron-nitrogen based hydrides and reactive composites for hydrogen storage. Mater. Today 2014, 17, 129-135. [CrossRef]

46. Jepsen, L.H.; Ley, M.B.; Filinchuk, Y.; Besenbacher, F.; Jensen, T.R. Tailoring the properties of ammine metal borohydrides for solid-state hydrogen storage. ChemSusChem 2015, 8, 1452-1463. [CrossRef] [PubMed]

47. Lai, Q.; Paskevicius, M.; Sheppard, D.A.; Buckley, C.E.; Thornton, A.W.; Hill, M.R.; Gu, Q.; Mao, J.; Huang, Z.; Liu, H.K.; et al. Hydrogen storage materials for mobile and stationary applications: Current state of the art. ChemSusChem 2015, 8, 2789-2825. [CrossRef] [PubMed]

48. Dovgaliuk, I.; Filinchuk, Y. Aluminium complexes of B- and N-based hydrides: Synthesis, structures and hydrogen storage properties. Int. J. Hydrogen Energy 2016, 41, 15489-15504. [CrossRef]

49. Mohtadi, R.; Orimo, S. The renaissance of hydrides as energy materials. Nat. Rev. Mater. 2016, $2,16091$. [CrossRef]

50. Paskevicius, M.; Jepsen, L.H.; Schouwink, P.; Cerny, R.; Ravnsbaek, D.B.; Filinchuk, Y.; Dornheim, M.; Besenbacher, F.; Jensen, T.R. Metal borohydrides and derivatives-Synthesis, structure and properties. Chem. Soc. Rev. 2017, 46, 1565-1634. [CrossRef] [PubMed]

51. Mirviss, S.B.; Dougherty, H.W.; Looney, R.W. Catalyst of Transition Metal Borohydride Complexes. U.S. Patent 3,310,547, 21 March 1961.

52. Marks, T.J.; Kolb, J.R. Covalent transition metal, lanthanide, and actinide tetrahydroborate complexes. Chem. Rev. 1977, 77, 263-293. [CrossRef]

53. Langer, R.; Iron, M.A.; Konstantinovski, L.; Diskin-Posner, Y.; Leitus, G.; Ben-David, Y.; Milstein, D. Iron Borohydride pincer complexes for the efficient hydrogenation of ketones under mild, base-free conditions: Synthesis and mechanistic insight. Chem. Eur. J. 2012, 18, 7196-7209. [CrossRef] [PubMed]

54. Chakraborty, S.; Lagaditis, P.O.; Förster, M.; Bielinski, E.A.; Hazari, N.; Holthausen, M.C.; Jones, W.D.; Schneider, S. Well-defined iron catalysts for the acceptorless reversible dehydrogenation-hydrogenation of alcohols and ketones. ACS Catal. 2014, 4, 3994-4003. [CrossRef]

55. Zell, T.; Ben-David, Y.; Milstein, D. Highly efficient, general hydrogenation of aldehydes catalyzed by PNP iron pincer complexes. Catal. Sci. Technol. 2015, 5, 822-826. [CrossRef]

56. Bhattacharyya, S.; Chatterjee, A.; Williamson, J.S. Reductive amination with zinc borohydride. efficient, safe route to fluorinated benzylamines. Synth. Commun. 1997, 27, 4265-4274. [CrossRef]

57. Ravikumar, K.S.; Sinha, S.; Chandrasekaran, S. Diastereoselectivity in the reduction of acyclic carbonyl compounds with diisopropoxytitanium(iii) tetrahydroborate. J. Org. Chem. 1999, 64, 5841-5844. [CrossRef]

58. Alinezhad, H.; Tajbakhsh, M.; Zamani, R. One-pot reductive amination of aldehydes and ketones using n-methyl-piperidine zinc borohydride (ZBNMPP) as a new reducing agent. Synlett 2006, 3, 431-0434. [CrossRef]

59. Firouzabadi, H.; Iranpoor, N.; Alinezhad, H. Micellar media catalyzed highly efficient reductive amination of carbonyl compounds with bis(triphenylphosphine)(tetrahydroborato)zirconium(II), $\left[\mathrm{Zr}\left(\mathrm{BH}_{4}\right)_{2}\left(\mathrm{Ph}_{3} \mathrm{P}\right)_{2}\right]$, as a new and a highly water tolerant tetrahydroborate reducing agent. J. Iran Chem. Soc. 2009, 6, 177-186. [CrossRef] 
60. Mohammadi, S.; Setamdideh, D. (Acridine)(tetrahydroborato) zinc complex $\left[\mathrm{Zn}\left(\mathrm{BH}_{4}\right)_{2}(\mathrm{acr})\right]$ : A new stable and efficient reducing agent. Orient. J. Chem. 2015, 31, 2395-2399. [CrossRef]

61. Abdollahpour, F.; Setamdideh, D. (Caffeine)(tetrahydroborato) zinc complex [ $\left.\mathrm{Zn}\left(\mathrm{BH}_{4}\right)_{2}(\mathrm{caf})\right]$ : A new stable and efficient reducing agent. Orient. J. Chem. 2015, 31, 1787-1792. [CrossRef]

62. Xu, Z.; Lin, Z. Transition metal tetrahydroborato complexes: An orbital interaction analysis of their structure and bonding. Coord. Chem. Rev. 1996, 156, 139-162. [CrossRef]

63. Makhaev, V.D. Structural and dynamic properties of tetrahydroborate complexes. Russ. Chem. Rev. 2000, 69, 727. [CrossRef]

64. Besora, M.; Lledós, A. Coordination modes and hydride exchange dynamics in transition metal tetrahydroborate. In Complexes Contemporary Metal Boron Chemistry I; Marder, T., Lin, Z., Eds.; Springer: Berlin, Germany, 2008; Volume 130, pp. 149-202.

65. Filippov, O.A.; Filin, A.M.; Tsupreva, V.N.; Belkova, N.V.; Lledós, A.; Ujaque, G.; Epstein, L.M.; Shubina, E.S. Proton-transfer and $\mathrm{H}_{2}$-elimination reactions of main-group hydrides $\mathrm{EH}_{4}{ }^{-}(\mathrm{E}=\mathrm{B}, \mathrm{Al}, \mathrm{Ga})$ with alcohols. Inorg. Chem. 2006, 45, 3086-3096. [CrossRef] [PubMed]

66. Golub, I.E.; Filippov, O.A.; Gulyaeva, E.S.; Gutsul, E.I.; Belkova, N.V. The interplay of proton accepting and hydride donor abilities in the mechanism of step-wise boron hydrides alcoholysis. Inorg. Chim. Acta 2017, 456, 113-119. [CrossRef]

67. Golub, I.E.; Filippov, O.A.; Gutsul, E.I.; Belkova, N.V.; Epstein, L.M.; Rossin, A.; Peruzzini, M.; Shubina, E.S. Dimerization mechanism of bis(triphenylphosphine)copper(I) tetrahydroborate: Proton transfer via a dihydrogen bond. Inorg. Chem. 2012, 51, 6486-6497. [CrossRef] [PubMed]

68. Belkova, N.V.; Bakhmutova-Albert, E.V.; Gutsul, E.I.; Bakhmutov, V.I.; Golub, I.E.; Filippov, O.A.; Epstein, L.M.; Peruzzini, M.; Rossin, A.; Zanobini, F.; et al. Dihydrogen bonding in complex $\left(\mathrm{PP}_{3}\right) \mathrm{RuH}\left(\eta^{1}-\mathrm{BH}_{4}\right)$ featuring two proton-accepting hydride sites: Experimental and theoretical studies. Inorg. Chem. 2014, 53, 1080-1090. [CrossRef] [PubMed]

69. Golub, I.E.; Filippov, O.A.; Belkova, N.V.; Epstein, L.M.; Rossin, A.; Peruzzini, M.; Shubina, E.S. Two pathways of proton transfer reaction to (triphos) $\mathrm{Cu}\left(\eta^{1}-\mathrm{BH}_{4}\right)$ via a dihydrogen bond [triphos = 1,1,1-tris(diphenylphosphinomethyl)ethane]. Dalton Trans. 2016, 45, 9127-9135. [CrossRef] [PubMed]

70. Golub, I.E.; Filippov, O.A.; Belkova, N.V.; Gutsul, E.I.; Epstein, L.M.; Rossin, A.; Peruzzini, M.; Shubina, E.S. Competition between the hydride ligands of two types in proton transfer to $\left[\left\{\kappa^{3}-\mathrm{P}-\mathrm{CH}_{3} \mathrm{C}\left(\mathrm{CH}_{2} \mathrm{CH}_{2} \mathrm{PPh}_{2}\right)_{3}\right\} \mathrm{RuH}\left(\eta^{2}-\mathrm{BH}_{4}\right)\right]$. Eur. J. Inorg. Chem. 2017. [CrossRef]

71. Haddad, P.S.; Mauro, A.E.; Frem, R.C. Borohidreto complexos de cobre (I) contendo difosfinas. caracterizacao espectroscopica c comportamento termico. Quim. Nova 2001, 24, 786-789. [CrossRef]

72. Frisch, M.; Trucks, G.; Schlegel, H.; Scuseria, G.; Robb, M.; Cheeseman, J.; Scalmani, G.; Barone, V.; Mennucci, B.; Petersson, G.; et al. Gaussian 09; Revision D. 01; Gaussian: Wallingford, CT, USA, 2009.

73. Zhao, Y.; Truhlar, D. The M06 suite of density functionals for main group thermochemistry, thermochemical kinetics, noncovalent interactions, excited states, and transition elements: Two new functionals and systematic testing of four M06-class functionals and 12 other functionals. Theor. Chim. Acta 2008, 120, 215-241.

74. Vosko, S.H.; Wilk, L.; Nusair, M. Accurate spin-dependent electron liquid correlation energies for local spin density calculations: A critical analysis. Can. J. Phys. 1980, 58, 1200-1211. [CrossRef]

75. Lee, C.; Yang, W.; Parr, R.G. Development of the Colle-Salvetti correlation-energy formula into a functional of the electron density. Phys. Rev. B 1988, 37, 785-789. [CrossRef]

76. Stephens, P.J.; Devlin, F.J.; Chabalowski, C.F.; Frisch, M.J. Ab initio calculation of vibrational absorption and circular dichroism spectra using density functional force fields. J. Phys. Chem. 1994, 98, 11623-11627. [CrossRef]

77. Becke, A.D. Density-functional exchange-energy approximation with correct asymptotic behavior. Phys. Rev. A 1988, 38, 3098-3100. [CrossRef]

78. Perdew, J.P.; Burke, K.; Ernzerhof, M. Generalized gradient approximation made simple. Phys. Rev. Lett. 1996, 77, 3865-3868. [CrossRef] [PubMed]

79. Swart, M.; Guell, M.; Luis, J.M.; Solà, M. Spin-state-corrected gaussian-type orbital basis sets. J. Phys. Chem. A 2010, 114, 7191-7197. [CrossRef] [PubMed] 
80. Hehre, W.J.; Ditchfield, R.; Pople, J.A. Self-Consistent molecular orbital methods. xii. further extensions of gaussian-Type basis sets for use in molecular orbital studies of organic molecules. J. Chem. Phys. 1972, 56, 2257-2261. [CrossRef]

81. Dill, J.D.; Pople, J.A. Self-consistent molecular orbital methods. XV. Extended gaussian-type basis sets for lithium, beryllium, and boron. J. Chem. Phys. 1975, 62, 2921-2923. [CrossRef]

82. Krishnan, R.; Binkley, J.S.; Seeger, R.; Pople, J.A. Self-consistent molecular orbital methods. XX. A basis set for correlated wave functions. J. Chem. Phys. 1980, 72, 650-654. [CrossRef]

83. Ditchfield, R.; Hehre, W.J.; Pople, J.A. Self-Consistent Molecular-Orbital Methods. IX. An Extended Gaussian-Type Basis for Molecular-Orbital Studies of Organic Molecules. J. Chem. Phys. 1971, 54, 724-728. [CrossRef]

84. Pietro, W.J.; Francl, M.M.; Hehre, W.J.; DeFrees, D.J.; Pople, J.A.; Binkley, J.S. Self-consistent molecular orbital methods. 24. Supplemented small split-valence basis sets for second-row elements. J. Am. Chem. Soc. 1982, 104, 5039-5048. [CrossRef]

85. Grimme, S. Semiempirical GGA-type density functional constructed with a long-range dispersion correction. J. Comput. Chem. 2006, 27, 1787-1799. [CrossRef] [PubMed]

86. Grimme, S.; Antony, J.; Ehrlich, S.; Krieg, H. A consistent and accurate ab initio parametrization of density functional dispersion correction (DFT-D) for the 94 elements H-Pu. J. Chem. Phys. 2010, 132, 154104. [CrossRef] [PubMed]

87. Grimme, S.; Ehrlich, S.; Goerigk, L. Effect of the damping function in dispersion corrected density functional theory. J. Comput. Chem. 2011, 32, 1456-1465. [CrossRef] [PubMed]

88. Fritsch, J.; Zundel, G. Influence of the polarity of the environment on easily polarizable $\mathrm{OH} \cdots \mathrm{N}=\mathrm{O}^{-} \cdots \mathrm{H}^{+} \mathrm{N}$ hydrogen bonds. J. Phys. Chem. 1981, 85, 556-561. [CrossRef]

89. Marenich, A.V.; Cramer, C.J.; Truhlar, D.G. Universal solvation model based on solute electron density and on a continuum model of the solvent defined by the bulk dielectric constant and atomic surface tensions. J. Phys. Chem. B 2009, 113, 6378-6396. [CrossRef] [PubMed]

90. Dong, L.; Wen, J.; Li, W. A theoretical investigation of substituent effects on the stability and reactivity of N-heterocyclic olefin carboxylates. Org. Biomol. Chem. 2015, 13, 8533-8544. [CrossRef] [PubMed]

91. Sumimoto, M.; Iwane, N.; Takahama, T.; Sakaki, S. Theoretical study of trans-metalation process in palladium-catalyzed borylation of iodobenzene with diboron. J. Am. Chem. Soc. 2004, 126, 10457-10471. [CrossRef] [PubMed]

92. Sheldrick, G. A short history of SHELX. Acta Cryst. A 2008, 64, 112-122. [CrossRef] [PubMed]

93. Xi, Z.; Jin, D. Preliminary study on the syntheses and structures of copper complexes with bidentate phosphine ligands. Chinese J. Inorg. Chem 1993, 9, 379-383.

94. Makhaev, V.; Borisov, A.; Baranetskaya, N.; Vil'chevskaya, V.; Gorelikova, Y.Y.; Krylova, A. Complexes of copper (I) tetrahydroborate with organometallic and polydentate phosphine ligands. Russ. J. Coord. Chem. $1992,18,416$.

95. Bommer, J.C.; Morse, K.W. Temperature-dependent phosphite complex equilibriums observable with NMR and IR. Inorg. Chem. 1981, 20, 1731-1734. [CrossRef]

96. Makhaev, V.D.; Borisov, A.P.; Lobkovskii, É.B.; Polyakova, V.B.; Semenenko, K.N. Preparation of hydroborate complexes of copper and an investigation of the dependence of their structure on the nature of the organophosphorus ligands. Russ. Chem. Bull. 1985, 34, 1731-1736. [CrossRef]

97. Khan, M.M.T.; Paul, P.; Venkatasubramanian, K. Synthesis and structural characterization of [ $\alpha, \alpha^{\prime}$-bis\{bis(2-(diphenylphosphino)ethyl)amino\}ethane] bis(tetrahydroborato)dicopper(I). Hydrogen bridge attachment of the tetrahydroborate group. Polyhedron 1991, 10, 1827-1829. [CrossRef]

98. Makhaev, A.; Dolghusin, F.; Yanovskii, A.; Struchkov, Y.T. Crystal and molecular structure of the benzene solvate of $\left[1,1^{\prime}\right.$-bis(diphenylphosphino)ferrocene]copper(i)eta^2-tetrahydridoborate $\left[\mathrm{Fe}\left(\mathrm{C}_{5} \mathrm{H}_{4} \mathrm{PPh}_{2}\right)_{2}\right]$ $\mathrm{CuBH}_{4} \cdot 2 \mathrm{C}_{6} \mathrm{H}_{6}$. Russ. J. Coord. Chem. 1996, 22, 573-577.

99. Lobkovskii, E.B.; Makhaev, V.D.; Borisov, A.P. Crystal and molecular structure of (tetrahydridoborato)bis(diphenylbutylphosphine)copper(I). J. Struct. Chem. 1984, 25, 496-498. [CrossRef]

100. Lippard, S.J.; Ucko, D. Transition metal borohydride complexes. II. Th reaction of copper(I) compounds with boron hydride anions. Inorg. Chem. 1968, 7, 1051-1056. [CrossRef] 
101. Makhaev, V.; Borisov, A.; Antsyshkina, A.; Sadikov, G.; Poraj-Koshits, M.; Kudrova, N.; Mal'tseva, N.; Istomin, S.Y. Synthesis and crystal structure of (1, 10-phenanthroline)-(triethylphosphite) copper (1) tetrahydroborate. Russ. J. Coord. Chem. 1993, 19, 858-863.

102. Green, B.E.; Kennard, C.H.L.; Smith, G.; Elcombe, M.M.; Moore, F.H.; James, B.D.; White, A.H. Crystal structures of $\alpha$ - and $\beta$-(1,10-phenanthroline)tetrahydroborato(triphenylphosphine)copper(I) and (2,9-dimethyl-4,7-diphenyl-1,10-phenanthroline)tetrahydroboratocopper(I). Inorg. Chim. Acta 1984, 83, 177-189. [CrossRef]

103. Bommer, J.C.; Morse, K.W. [( $\left.\left.\mathrm{MePh}_{2} \mathrm{P}\right)_{3} \mathrm{CuBH}_{4}\right]$ : A single M-H bridged tetrahydroborate. J. Chem. Soc. Chem. Commun. 1977, 137-138. [CrossRef]

104. Bianchini, C.; Ghilardi, C.A.; Meli, A.; Midollini, S.; Orlandini, A. Reactivity of copper(I) tetrahydroborates toward carbon dioxide and carbonyl sulfide. Structure of (triphos) $\mathrm{Cu}\left(\eta^{1}-\mathrm{O}_{2} \mathrm{CH}\right)$. Inorg. Chem. 1985, 24, 924-931. [CrossRef]

105. Li, J.; White, J.M.; Mulder, R.J.; Reid, G.E.; Donnelly, P.S.; O’Hair, R.A.J. Synthesis, structural characterization, and gas-phase unimolecular reactivity of bis(diphenylphosphino)amino copper hydride nanoclusters $\left[\mathrm{Cu}_{3}(\mathrm{X})\left(\mu_{3}-\mathrm{H}\right)\left(\left(\mathrm{PPh}_{2}\right)_{2} \mathrm{NH}\right)_{3}\right]\left(\mathrm{BF}_{4}\right)$, where $\mathrm{X}=\mu_{2}-\mathrm{Cl}$ and $\mu_{3}-\mathrm{BH}_{4}$. Inorg. Chem. 2016, 55, 9858-9868. [CrossRef] [PubMed]

106. Li, Q.-Z.; Dong, X.; Jing, B.; Li, W.-Z.; Cheng, J.-B.; Gong, B.-A.; Yu, Z.-W. A new unconventional halogen bond $\mathrm{C}-\mathrm{X} \cdots \mathrm{H}-\mathrm{M}$ between $\mathrm{HCCX}(\mathrm{X}=\mathrm{Cl}$ and $\mathrm{Br})$ and $\mathrm{HMH}(\mathrm{M}=\mathrm{Be}$ and $\mathrm{Mg})$ : An Ab Initio study. J. Comput. Chem. 2010, 31, 1662-1669. [CrossRef] [PubMed]

107. Smith, D.A.; Brammer, L.; Hunter, C.A.; Perutz, R.N. Metal hydrides form halogen bonds: Measurement of energetics of binding. J. Am. Chem. Soc. 2013, 136, 1288-1291. [CrossRef] [PubMed]

108. Lipkowski, P.; Grabowski, S.J.; Leszczynski, J. Properties of the halogen-hydride interaction: An ab initio and "atoms in molecules" analysis. J. Phys. Chem. A 2006, 110, 10296-10302. [CrossRef] [PubMed]

109. Mohajeri, A.; Alipour, M.; Mousaee, M. Halogen-hydride interaction between $Z-X(Z=C N, N C ; X=F, C l$, $\mathrm{Br})$ and $\mathrm{H}-\mathrm{Mg}-\mathrm{Y}\left(\mathrm{Y}=\mathrm{H}, \mathrm{F}, \mathrm{Cl}, \mathrm{Br}, \mathrm{CH}_{3}\right)$. J. Phys. Chem. A 2011, 115, 4457-4466. [CrossRef] [PubMed]

110. Jabłoński, M.; Palusiak, M. Nature of a hydride-halogen bond. A SAPT-, QTAIM-, and NBO-based study. J. Phys. Chem. A 2012, 116, 2322-2332. [CrossRef] [PubMed]

111. Esrafili, M.D.; Solimannejad, M. Revealing substitution effects on the strength and nature of halogen-hydride interactions: A theoretical study. J. Mol. Model. 2013, 19, 3767-3777. [CrossRef] [PubMed]

112. Bai, X.; Li, Q.; Li, R.; Cheng, J.; Li, W. Is a $\mathrm{MH}(\mathrm{M}=\mathrm{Be}$ and $\mathrm{Mg})$ radical a better electron donor in halogen-hydride interaction?: A theoretical comparison with HMH. Int. J. Quantum Chem. 2013, 113, 1293-1298. [CrossRef]

113. Anufriev, S.A.; Sivaev, I.B.; Suponitsky, K.Y.; Bregadze, V.I. Practical synthesis of 9-methylthio-7,8-nido-carborane [9-MeS-7,8-C2B9H11] ${ }^{-}$. Some evidences of $\mathrm{BH} \cdots \mathrm{X}$ hydride-halogen bonds in 9- $\mathrm{XCH}_{2}(\mathrm{Me}) \mathrm{S}-7,8-\mathrm{C}_{2} \mathrm{~B}_{9} \mathrm{H}_{11}$ $(\mathrm{X}=\mathrm{Cl}, \mathrm{Br}, \mathrm{I})$. J. Organomet. Chem. 2017. [CrossRef]

114. Moudam, O.; Kaeser, A.; Delavaux-Nicot, B.; Duhayon, C.; Holler, M.; Accorsi, G.; Armaroli, N.; Seguy, I.; Navarro, J.; Destruel, P.; et al. Electrophosphorescent homo- and heteroleptic copper(i) complexes prepared from various bis-phosphine ligands. Chem. Commun. 2007, 3077-3079. [CrossRef] [PubMed]

115. Kaeser, A.; Mohankumar, M.; Mohanraj, J.; Monti, F.; Holler, M.; Cid, J.-J.; Moudam, O.; Nierengarten, I.; Karmazin-Brelot, L.; Duhayon, C.; et al. Heteroleptic copper(I) complexes prepared from phenanthroline and bis-phosphine ligands. Inorg. Chem. 2013, 52, 12140-12151. [CrossRef] [PubMed]

116. Bilyachenko, A.N.; Kulakova, A.N.; Levitsky, M.M.; Petrov, A.A.; Korlyukov, A.A.; Shul'pina, L.S.; Khrustalev, V.N.; Dorovatovskii, P.V.; Vologzhanina, A.V.; Tsareva, U.S.; et al. Unusual tri-, hexa-, and nonanuclear $\mathrm{Cu}(\mathrm{II})$ cage methylsilsesquioxanes: Synthesis, structures, and catalytic activity in oxidations with peroxides. Inorg. Chem. 2017, 56, 4093-4103. [CrossRef] [PubMed]

(C) 2017 by the authors. Licensee MDPI, Basel, Switzerland. This article is an open access article distributed under the terms and conditions of the Creative Commons Attribution (CC BY) license (http://creativecommons.org/licenses/by/4.0/). 